\title{
Fractional crystallization of
}

\section{primitive, hydrous arc magmas: an experimental study at $0.7 \mathrm{GPa}$}

\section{Journal Article}

Author(s):

Nandedkar, Rohit H.; Ulmer, Peter (D); Müntener, Othmar

Publication date:

2014-05-20

Permanent link:

https://doi.org/10.3929/ethz-b-000087224

Rights / license:

In Copyright - Non-Commercial Use Permitted

Originally published in:

Contributions to Mineralogy and Petrology 167(6), https://doi.org/10.1007/s00410-014-1015-5 


\title{
Fractional crystallization of primitive, hydrous arc magmas: an experimental study at $0.7 \mathrm{GPa}$
}

\author{
Rohit H. Nandedkar · Peter Ulmer • \\ Othmar Müntener
}

Received: 6 December 2013/Accepted: 5 May 2014/Published online: 20 May 2014

(C) Springer-Verlag Berlin Heidelberg 2014

\begin{abstract}
Differentiation of mantle-derived, hydrous, basaltic magmas is a fundamental process to produce evolved intermediate to $\mathrm{SiO}_{2}$-rich magmas that form the bulk of the middle to shallow continental and island arc crust. This study reports the results of fractional crystallization experiments conducted in a piston cylinder apparatus at $0.7 \mathrm{GPa}$ for hydrous, calc-alkaline to arc tholeiitic magmas. Fractional crystallization was approached by synthesis of starting materials representing the liquid composition of the previous, higher temperature experiment. Temperatures ranged from near-liquidus at $1,170{ }^{\circ} \mathrm{C}$ to near-solidus conditions at $700{ }^{\circ} \mathrm{C}$. $\mathrm{H}_{2} \mathrm{O}$ contents varied from 3.0 to more than $10 \mathrm{wt} \%$. The liquid line of descent covers the entire compositional range from olivine-tholeiite $\left(1,170{ }^{\circ} \mathrm{C}\right)$ to high-silica rhyolite $\left(700{ }^{\circ} \mathrm{C}\right)$ and evolves from metaluminous to peraluminous compositions. The following crystallization sequence has been established: olivine $\rightarrow$ clinopyroxene $\rightarrow$ plagioclase, spinel $\rightarrow$ orthopyroxene, amphibole, titanomagnetite $\rightarrow$ apatite $\rightarrow$ quartz, biotite. Anorthite-rich plagioclase and spinel are responsible for a marked increase in $\mathrm{SiO}_{2}$-content (from 51 to $53 \mathrm{wt} \%$ ) at $1,040{ }^{\circ} \mathrm{C}$. At lower temperatures,
\end{abstract}

Communicated by T. L. Grove.

Electronic supplementary material The online version of this article (doi:10.1007/s00410-014-1015-5) contains supplementary material, which is available to authorized users.

R. H. Nandedkar · P. Ulmer $(\bowtie)$

Institute of Geochemistry and Petrology, ETH,

Clausiusstrasse 25, 8092 Zürich, Switzerland

e-mail: peter.ulmer@erdw.ethz.ch

O. Müntener

Institute of Earth Sciences, Géopolis 4897, 1015 Lausanne,

Switzerland fractionation of amphibole, plagioclase and $\mathrm{Fe}-\mathrm{Ti}$ oxide over a temperature interval of $280{ }^{\circ} \mathrm{C}$ drives the $\mathrm{SiO}_{2}$ content continuously from 53 to $78 \mathrm{wt} \%$. Largest crystallization steps were recorded around $1,040{ }^{\circ} \mathrm{C}$ and at $700{ }^{\circ} \mathrm{C}$. About $40 \%$ of ultramafic plutonic rocks have to crystallize to generate basaltic-andesitic liquids, and an additional $40 \%$ of amphibole-gabbroic cumulate to produce granitic melts. Andesitic liquids with a liquidus temperature of $1,010^{\circ} \mathrm{C}$ only crystallize $50 \%$ over an $280{ }^{\circ} \mathrm{C}$ wide range to $730{ }^{\circ} \mathrm{C}$ implying that such liquids form mobile crystal mushes $(<50 \%$ crystals) in long-lived magmatic systems in the middle crust, allowing for extensive fractionation, assimilation and hybridization with periodic replenishment of more mafic magmas from deeper magma reservoirs.

Keywords Liquid line of descent - Fractional crystallization · Calc-alkaline magmas · Mid-crustal magma reservoirs

\section{Introduction}

Voluminous intermediate to granitic rocks forming large batholiths and associated volcanic provinces typically occur in supra-subduction, arc-related settings such as the Peruvian coastal batholiths, the Californian batholith (USA), the Patagonian batholith (Chile), the Himalaya batholith or on a smaller scale, the Tertiary Adamello batholith (Northern Italy). For their origin, a number of processes have been invoked such as fractional crystallization from mantle-derived basaltic precursors (e.g., Bowen 1928; Cawthorn et al. 1976; Sisson and Grove 1993a, b; Ulmer 2001), additional extensive assimilation of and hybridization with crustally derived partial melts 
generated by heating of mantle-derived magmas over prolonged time (Hildreth and Moorbath 1988; Blatter et al. 2013) as well as exclusive partial melting of deep-crustal lithologies (mafic amphibolites to granulites, e.g., Rapp and Watson (1995), as well as pelitic micaschists, e.g., Clemens et al. (2011)). In order to identify and quantify the relative significance of these processes, phase equilibria, major and trace element compositions, and partitioning behavior of the products generated by the proposed endmember processes need to be known. In this contribution, we focus on fractional crystallization of hydrous, calcalkaline to tholeiitic arc-type primary to parental melts at pressure conditions corresponding to mid-crustal levels (0.7 GPa, 20-25 km). Our data complement similar studies conducted in our laboratory and elsewhere that cover the deep-crustal levels (e.g., Alonso-Perez 2006; Whitaker et al. 2008; Ulmer et al. 2014). The focus of this study is twofold: (1) To identify the phase equilibrium controls on the fractionation paths of calc-alkaline magmas and (2) to quantify the liquid line of descent from the basaltic liquidus to granitic derivative liquids close to the granite solidus. This study contributes at evaluating the mineralogy, mineral chemistry and modal proportions of products generated through fractional crystallization and ultimately provides arguments in favor of, or in contradiction to the potential derivation of silicic magmas by fractional crystallization of precursor basaltic magmas, a subject that is highly controversial (e.g., Clemens et al. 2011; Jagoutz et al. 2011; Melekhova et al. 2013) but intimately linked to the generation of the continental crust.

An ancillary goal of these experimental series at $0.7 \mathrm{GPa}$ was to test the hypothesis that up to $50 \%$ crystallization of ultramafic rocks from initial, mantle-derived liquids must have taken place to produce andesitic liquids (e.g., Kay and Kay 1991; Müntener et al. 2001; Müntener and Ulmer 2006; Jagoutz et al. 2011). Quantitative assessment of the compositions of derivative liquids as well as the modal proportions of fractionated solids furthermore directly contributes to a better understanding of the rheology of such magmas as crystallinity and rheology of suspending silicate liquid are the two most important parameters governing the ascent and intrusion/eruption modes of intermediate to silicic magmas (e.g., Clemens and Mawer 1992; Brown and Solar 1998; Paterson et al. 1998; Caricchi et al. 2007).

\section{Experimental techniques}

\section{Experimental strategy}

In this study, (near) fractional crystallization was approached in a stepwise manner. A synthetic equivalent of a natural, near-primary olivine-tholeiite composition was used as initial starting material containing $3.0 \mathrm{wt} \% \mathrm{H}_{2} \mathrm{O}$ to locate the liquidus (Table 1). Thereafter, the liquid composition coexisting with small to moderate amounts of solid phases was determined by electron probe microanalysis (EPMA), and for any subsequent experiment, a new starting material corresponding to the liquid composition of the previous, higher temperature experiment was synthesized. The temperature steps between successive experiments were generally $30^{\circ} \mathrm{C}$; at lowest temperatures, $50{ }^{\circ} \mathrm{C}$ steps were employed and for intervals where significant $(>20 \%)$ crystallization occurred an additional experiment was set between 2 fractionation steps. All experiments were evaluated by least-square regression analysis using the known starting composition and the

Table 1 Compositions of starting materials in wt $\%$

\begin{tabular}{|c|c|c|c|c|c|c|c|c|c|c|c|c|c|}
\hline St.mat. & $\mathrm{SiO}_{2}$ & $\mathrm{TiO}_{2}$ & $\mathrm{Al}_{2} \mathrm{O}_{3}$ & $\mathrm{Fe}_{2} \mathrm{O}_{3}$ & $\mathrm{FeO}$ & $\mathrm{MnO}$ & $\mathrm{MgO}$ & $\mathrm{CaO}$ & $\mathrm{Na}_{2} \mathrm{O}$ & $\mathrm{K}_{2} \mathrm{O}$ & $\mathrm{P}_{2} \mathrm{O}_{5}$ & $\mathrm{H}_{2} \mathrm{O}$ & Total \\
\hline RDC156 & 48.43 & 0.68 & 15.19 & 1.64 & 6.65 & 0.15 & 10.13 & 11.57 & 1.86 & 0.59 & 0.10 & 3.00 & 100.00 \\
\hline RN4 & 48.42 & 0.72 & 15.42 & 1.72 & 6.80 & 0.17 & 9.39 & 11.71 & 1.90 & 0.61 & 0.10 & 3.04 & 100.00 \\
\hline RN6V2 & 48.53 & 0.74 & 15.97 & 1.73 & 6.78 & 0.17 & 8.46 & 11.75 & 1.97 & 0.63 & 0.11 & 3.17 & 100.00 \\
\hline RN7 & 48.34 & 0.78 & 18.01 & 1.74 & 6.80 & 0.17 & 6.95 & 10.42 & 2.26 & 0.73 & 0.12 & 3.69 & 100.00 \\
\hline RN8 & 50.20 & 0.84 & 18.82 & 1.71 & 6.71 & 0.17 & 4.54 & 8.02 & 2.90 & 0.97 & 0.16 & 4.96 & 100.00 \\
\hline RN9 & 53.85 & 0.63 & 18.58 & 1.31 & 5.16 & 0.17 & 2.64 & 6.78 & 3.21 & 1.20 & 0.21 & 6.26 & 100.00 \\
\hline RN10 & 56.05 & 0.60 & 18.18 & 0.90 & 3.26 & 0.16 & 2.66 & 6.45 & 3.40 & 1.29 & 0.22 & 6.82 & 100.00 \\
\hline RN11 & 57.92 & 0.61 & 16.72 & 0.88 & 3.04 & 0.18 & 2.28 & 5.22 & 3.63 & 1.46 & 0.26 & 7.81 & 100.00 \\
\hline RN12 & 59.62 & 0.50 & 16.62 & 0.67 & 2.20 & 0.17 & 1.50 & 4.57 & 3.81 & 1.58 & 0.28 & 8.49 & 100.00 \\
\hline RN13V2 & 61.40 & 0.26 & 15.67 & 0.47 & 1.47 & 0.18 & 1.59 & 3.79 & 4.00 & 1.72 & 0.30 & 9.15 & 100.00 \\
\hline RN14V2 & 61.49 & 0.25 & 15.28 & 0.46 & 1.38 & 0.17 & 1.30 & 3.26 & 4.06 & 1.76 & 0.23 & 10.36 & 100.00 \\
\hline RN15V2 & 63.83 & 0.17 & 14.71 & 0.34 & 0.96 & 0.17 & 1.26 & 2.49 & 4.29 & 1.90 & 0.16 & 9.70 & 100.00 \\
\hline RN16V2 & 65.60 & 0.12 & 13.52 & 0.26 & 0.66 & 0.15 & 0.90 & 1.34 & 4.45 & 2.11 & 0.10 & 10.79 & 100.00 \\
\hline RN17V2 & 67.99 & 0.11 & 12.24 & 0.20 & 0.45 & 0.11 & 0.64 & 0.52 & 4.44 & 2.37 & 0.04 & 10.89 & 100.00 \\
\hline
\end{tabular}


Table 2 Experimental run conditions and phase relations of fractional crystallization experiments at 0.7 GPa (inner/single capsules)

\begin{tabular}{|c|c|c|c|c|c|c|c|c|c|c|}
\hline Run \# & $\mathrm{sm}^{\mathrm{a}}$ & $\begin{array}{l}\text { Temp } \\
\left({ }^{\circ} \mathrm{C}\right)\end{array}$ & $\begin{array}{l}\text { Time } \\
\text { (h) }\end{array}$ & $\begin{array}{l}\text { Capsule } \\
\text { material }\end{array}$ & Phase assemblages & Phase proportions ${ }^{\mathrm{b}}$ (wt $\%$ ) & $\sum \mathrm{R}^{2}$ & $\begin{array}{l}\Delta \mathrm{Fe} \\
\text { (\%rel.) }\end{array}$ & $\begin{array}{l}\mathrm{fO}_{2} \\
\Delta \mathrm{NNO}\end{array}$ & $\begin{array}{l}\text { Liq } \\
(\text { abs })\end{array}$ \\
\hline RN1 & RDC156 & 1,170 & 4 & $\mathrm{Au}_{90} \mathrm{Pd}_{10}$ & liq, $v$ & 100 & 0.52 & -1.4 & & 100.0 \\
\hline RN2 & RDC156 & 1,150 & 28 & $\mathrm{Au}_{90} \mathrm{Pd}_{10}$ & liq, ol, v & $98.1(8), 1.9(6)$ & 0.37 & -1.5 & 0.33 & 98.1 \\
\hline RN5 & RN4 & 1,100 & 12 & $\mathrm{Au}_{90} \mathrm{Pd}_{10}$ & liq, ol, cpx, v & $94.1(13), 3.8(5), 2.1(14)$ & 0.20 & -2.4 & 1.07 & 92.3 \\
\hline RN6 & RN6V2 & 1,070 & 24 & $\mathrm{Au}_{90} \mathrm{Pd}_{10}$ & liq, ol, cpx, v & $86.1(6), 0.9(3), 13.0(6)$ & 0.06 & 9.1 & & 79.5 \\
\hline RN7W2 & RN7 & 1,055 & 47 & $\mathrm{Au}_{90} \mathrm{Pd}_{10}$ & liq, cpx, v & $94.7(27), 5.3(4)$ & 0.03 & 6.5 & & 75.3 \\
\hline RN7 & RN7 & 1,040 & 48 & $\mathrm{Au}_{90} \mathrm{Pd}_{10}$ & $\begin{array}{l}\text { liq, cpx, (opx), } \\
\text { plag, sp, v }\end{array}$ & $\begin{array}{l}\text { 75.7(43), 19.7(29), 2.2(36) } \\
0.72^{\mathrm{c}}\end{array}$ & 0.80 & 6.5 & & 60.2 \\
\hline RN8W2 & RN8 & 1,025 & 49 & $\mathrm{Au}_{90} \mathrm{Pd}_{10}$ & liq, (plag), v & 100 & 0.11 & 5.5 & & 60.2 \\
\hline RN8 & RN8 & 1,010 & 48 & $\mathrm{Au}_{90} \mathrm{Pd}_{10}$ & $\begin{array}{l}\text { liq, opx, plag, } \\
\text { amph, mag, v }\end{array}$ & $\begin{array}{l}\text { 74.4(7), 0.8(10), 6.8(11), } \\
16.6(16), 1.4(5)\end{array}$ & 0.01 & 2.4 & & 44.8 \\
\hline RN9 & RN9 & 980 & 48 & $\mathrm{Au}_{90} \mathrm{Pd}_{10}$ & liq, plag, mag, v & $91.8(11), 5.1(12), 0.7^{c}$ & 0.28 & -0.4 & & 41.1 \\
\hline RN10s & RN10 & 950 & 48 & $\mathrm{Au}$ & $\begin{array}{l}\text { liq, opx, plag, } \\
\text { amph, v }\end{array}$ & $\begin{array}{l}\text { 86.0(16), 0.4(29), 10.0(24), } \\
3.6(48)\end{array}$ & 0.18 & 5.0 & & 35.3 \\
\hline RN11V2 & RN11 & 920 & 56 & $\mathrm{Au}$ & $\begin{array}{l}\text { liq, plag, amph, } \\
\text { mag, (usp), v }\end{array}$ & $90.9(7), 2.8(6), 5.5(8), 0.18^{c}$ & 0.06 & -0.2 & & 32.1 \\
\hline RN12V2-2 & RN12 & 890 & 56 & $\mathrm{Au}$ & $\begin{array}{l}\text { liq, plag, amph, } \\
\text { mag, v }\end{array}$ & $\begin{array}{l}86.4(11), 10.9(11), 1.3(14) \\
0.18^{c}\end{array}$ & 0.21 & 2.3 & & 27.8 \\
\hline RN13V2 & RN13V2 & 860 & 72 & $\mathrm{Au}$ & $\begin{array}{l}\text { liq, plag, amph, } \\
\text { ap, v }\end{array}$ & $\begin{array}{l}96.1(19), 2.0(16), 1.9(23), \\
0.16^{c}\end{array}$ & 0.70 & -0.6 & & 26.7 \\
\hline RN14V2 & RN14V2 & 830 & 75 & $\mathrm{Au}$ & $\begin{array}{l}\text { liq, plag, amph, } \\
\text { mag, ap, v }\end{array}$ & $\begin{array}{l}93.0(27), 5.6(22), 0.7(34) \\
0.8(7), 0.20^{c}\end{array}$ & 1.04 & 1.8 & & 24.8 \\
\hline RN15V2 & RN15V2 & 780 & 100 & $\mathrm{Au}$ & $\begin{array}{l}\text { liq, plag, amph, } \\
\text { mag, ap, v }\end{array}$ & $\begin{array}{l}88.5(20), 8.7(18), 2.6(22) \\
0.3(5), 0.18^{c}\end{array}$ & 0.54 & 1.7 & & 22.0 \\
\hline RN16V2 & RN16V2 & 730 & 100 & $\mathrm{Au}$ & $\begin{array}{l}\text { liq, plag, amph, } \\
\text { mag, ap, v }\end{array}$ & $\begin{array}{l}87.8(25), 10.4(22), 1.7(20) \\
0.2(5), 0.07^{c}\end{array}$ & 0.52 & 1.6 & & 19.3 \\
\hline RN17V2 & RN17V2 & 700 & 168 & $\mathrm{Au}$ & $\begin{array}{l}\text { liq, plag, mag, qtz, } \\
\text { bt, ap, v }\end{array}$ & $\begin{array}{l}73.9(20), 12.0(8), 0.2(1) \\
10.5(10), 3.4(4), 0.03\end{array}$ & 0.55 & -0.9 & & 14.2 \\
\hline
\end{tabular}

Phases in brackets correspond to phases present in experiment, but whose modal proportions were insignificant (not calculated)

Abbreviations for phases: liq-liquid (glass), ol—olivine, cpx—high-Ca clinopyroxene, opx-low-Ca orthopyroxene, plag-plagioclase, sphercynitic spinel, mag — titanomagnetite, usp—ulvospinel, amph—amphibole, ap—apatite, qtz-quartz, bt—biotite, v—vapor (bubble)

$\Delta \mathrm{Fe}: \mathrm{FeO}$ loss or gain (in relative percent; negative numbers = gain) from the starting material based on mass balance calculations

$\sum \mathrm{R}^{2}$ : residual sum of squares

$\mathrm{fO}_{2} \Delta$ NNO: $\log \mathrm{fO}_{2}$ (NNO)-log $\mathrm{fO}_{2}$ (experiment) based on ol-liq $\mathrm{Fe}^{2+}-\mathrm{Mg}$ partitioning and the model of Kress and Carmichael (1988)

${ }^{a}$ Compositions of starting materials are given in Table 1

${ }^{\mathrm{b}}$ Units in parentheses represent the error from regression analysis. Accordingly, 94.1 (13) is read as $94.1 \pm 1.3$

${ }^{c}$ Phase proportion of Fe-Ti oxide determined by image analysis

compositions of all coexisting phases (glass and solid phase) to compute modal proportions (Tables 1, 2) to ensure closed system behavior, to detect potential disequilibrium, to calculate the correct amount of $\mathrm{H}_{2} \mathrm{O}$ to add to the next, lower-temperature starting material, and to account for potential alkali deficits in the EPMA analyses (mainly caused by $\mathrm{Na}$ migration in silicate liquids), and iron loss to noble-metal sample containers.

\section{Starting materials}

A synthetic equivalent of a near-primary olivine-tholeiite dike composition from the southern part of the Tertiary
Adamello batholith (RC156, coordinates: $45^{\circ} 57^{\prime} 08.04^{\prime \prime} \mathrm{N}$ $10^{\circ} 26^{\prime} 33.08^{\prime \prime}$ E elevation: 2,344 m) was used as an initial starting composition (Table 1). The particular dike consists of olivine (forsterite content (Fo) 91.1) and clinopyroxene $\left(\mathrm{Mg}\right.$-number $(\mathrm{Mg} \#)=$ molar $\mathrm{MgO} / \mathrm{MgO}+\mathrm{FeO}_{\text {tot }}$ of 0.87) phenocrysts both containing minute, idiomorphic $\mathrm{Cr}$-spinel inclusions in a fine-grained matrix composed of plagioclase, amphibole and minor magnetite (Ulmer 1986). The trace element signature clearly reveals the subductionrelated provenance (HFSE depletion, LREE and LILE enrichment) of this dike that is post-plutonic, cross-cutting the tonalites of the southern Adamello batholiths (Hürlimann et al. 2014). A similar, but even more primitive 
composition (RC158c), a picrobasalt from the same dikerock association has been utilized as starting material for the higher pressure, equilibrium and fractional crystallization experiments at 1.0 (Müntener and Ulmer 2006; Ulmer et al. 2014) and 1.5 GPa (Alonso-Perez 2006; Müntener and Ulmer 2006). In order to avoid a large number of experiments that solely crystallize olivine, a less Mg-rich composition has been selected for this study. However, the two compositions, RC158c and RC156, are part of the same dike generation and are directly linked by moderate (up to $15 \%$ ) olivine fractionation (see Hürlimann et al. 2014).

All liquid compositions (Table 1) were mixed from fired $\left(1,000{ }^{\circ} \mathrm{C}: \mathrm{SiO}_{2}, \mathrm{TiO}_{2}, \mathrm{Fe}_{2} \mathrm{O}_{3}, \mathrm{MgO}\right.$ and $\left.\mathrm{CaSiO}_{3}\right)$ and dried (220-350 ${ }^{\circ} \mathrm{C}: \gamma-\mathrm{Al}_{2} \mathrm{O}_{3}, \mathrm{MnO}, \mathrm{Fe}_{2} \mathrm{SiO}_{4}, \mathrm{Na}_{2} \mathrm{SiO}_{3}, \mathrm{~K}_{4} \mathrm{Si}_{5} \mathrm{O}_{12}$ and $\mathrm{Ca}_{5}\left(\mathrm{PO}_{4}\right)_{3}(\mathrm{OH})$ oxides and silicates), and dried mixtures of $\mathrm{AlOOH}\left(200{ }^{\circ} \mathrm{C}\right)$ and $\mathrm{Al}(\mathrm{OH})_{3}\left(100{ }^{\circ} \mathrm{C}\right)$ to adjust the desired $\mathrm{H}_{2} \mathrm{O}$ content provided the alumina concentration of the target composition was high enough. In the last fractionation steps where $\mathrm{Al}_{2} \mathrm{O}_{3}$ concentrations were low and $\mathrm{H}_{2} \mathrm{O}$ concentrations high, distilled water was added by a micro-syringe to an anhydrous powder mixture during preparation of the capsules. In order to determine trace element partitioning between solid phases and the quenched liquids (glass), all starting material additionally contained $2 \mathrm{wt} \%$ of a trace element-doped diopside glass (32 trace element at 2,000 $\mu \mathrm{g} / \mathrm{g}$ level, except Th and U (1,000 $\mu \mathrm{g} / \mathrm{g})$ providing $40(\mathrm{U}, \mathrm{Th} 20) \mu \mathrm{g} / \mathrm{g}$ of trace element encompassing all important classes of trace elements (LILE, REE, HFSE, transition metals). The thoroughly mixed, fine-grained oxide-silicate-hydrate starting materials were directly employed in this experimental study without any further treatment.

Oxygen fugacity $\left(\mathrm{fO}_{2}\right)$ was constrained by fixing the ratio of ferrous to ferric iron in the starting material using the algorithm of Kress and Carmichael (1991) for liquids to a value corresponding to the $\mathrm{Ni}-\mathrm{NiO}$ buffer equilibrium (NNO) at the conditions of the experiment (pressure of $0.7 \mathrm{GPa}$ and respective run temperature). This approach is only strictly valid when the charge would be composed entirely of liquid; therefore, in the present work, this is only an approximation as the amount of liquid varied between 100 and $75 \%$. In the absence of $\mathrm{Fe}-\mathrm{Ti}$ oxides, the $\mathrm{fO}_{2}$ most likely increases in the charges due to the more incompatible behavior of ferric relative to ferrous iron in the presence of olivine and clinopyroxene that dominate in the higher temperature steps. At lower temperature, prediction is more difficult as both $\mathrm{Fe}$-Ti oxide and amphibole can accommodate significant amounts of ferric relative to ferrous iron. However, in these experiments, the liquid fraction always exceeded $84 \%$; therefore, we do not expect significant deviation from the target $\mathrm{fO}_{2}$ due to crystallization of the solid phases. However, a prerequisite for successful application of this technique is the absence of significant hydrogen and/or iron loss during the experiment, i.e., the system behaved as a closed system. Hydrogen diffusion was minimized by employing the double-capsule technique described by Kägi et al. (2005). $\mathrm{Fe}$ loss was minimized using $\mathrm{Au}_{90} \mathrm{Pd}_{10}$ sample container material above $1,000{ }^{\circ} \mathrm{C}$ and pure Au below $1,000{ }^{\circ} \mathrm{C}$ and by minimizing the run duration to the minimum required for equilibration.

In runs where olivine formed a liquidus phase (at highest temperatures), the olivine-liquid $\mathrm{Fe}^{2+}-\mathrm{Mg}$ partitioning could be utilized to estimate $\mathrm{fO}_{2}$ during the experiments (Ulmer 1989; Kägi et al. 2005) (see Table 2) and confirmed that $\mathrm{fO}_{2}$ remained close to slightly above the targeted NNO values.

Table $3 \mathrm{H}_{2} \mathrm{O}$ contents of liquids (glasses) in fractional crystallization experiments at $0.7 \mathrm{GPa}$ calculated from added $\mathrm{H}_{2} \mathrm{O}$ and determined by Raman spectroscopy

\begin{tabular}{|c|c|c|c|c|c|}
\hline Run\# & $\begin{array}{l}\text { Temp. } \\
\left({ }^{\circ} \mathrm{C}\right)\end{array}$ & Capsule & $\begin{array}{l}\mathrm{H}_{2} \mathrm{O} \text { added } \\
(\mathrm{wt} \%)^{\mathrm{a}}\end{array}$ & $\begin{array}{l}\mathrm{H}_{2} \mathrm{O} \text { Raman } \\
(\mathrm{wt} \%)^{\mathrm{b}}\end{array}$ & $2 \sigma$ \\
\hline \multirow[t]{2}{*}{ RN1 } & \multirow[t]{2}{*}{1,170} & inner & 3.00 & 3.6 & 0.2 \\
\hline & & outer & 3.06 & 3.3 & 0.1 \\
\hline \multirow[t]{2}{*}{ RN2 } & \multirow[t]{2}{*}{1,140} & inner & 3.06 & 3.1 & 0.1 \\
\hline & & outer & 3.06 & 3.3 & 0.1 \\
\hline \multirow[t]{2}{*}{ RN4 } & \multirow[t]{2}{*}{1,120} & inner & 3.05 & 5.1 & 0.1 \\
\hline & & outer & 3.05 & 3.9 & 0.1 \\
\hline \multirow[t]{2}{*}{ RN5 } & \multirow[t]{2}{*}{1,110} & inner & 3.23 & 3.2 & 0.1 \\
\hline & & outer & 3.17 & 3.4 & 0.2 \\
\hline \multirow[t]{2}{*}{ RN6 } & \multirow[t]{2}{*}{1,070} & inner & 3.68 & 4.2 & 0.2 \\
\hline & & outer & 3.77 & 4.4 & 0.4 \\
\hline \multirow[t]{2}{*}{ RN7 } & \multirow[t]{2}{*}{1,040} & inner & 4.87 & 5.3 & 0.1 \\
\hline & & outer & 4.84 & 5.0 & 0.2 \\
\hline \multirow[t]{2}{*}{ RN8 } & \multirow[t]{2}{*}{1,010} & inner & 6.20 & 6.2 & 0.1 \\
\hline & & outer & 6.06 & 6.8 & 0.5 \\
\hline RN10s & 950 & single & 7.84 & 7.8 & 0.4 \\
\hline RN11 & 920 & single & 8.46 & 8.7 & 0.3 \\
\hline RN12V2-2 & 890 & single & 9.79 & 7.9 & 0.3 \\
\hline RN13V2 & 860 & single & 9.48 & 9.9 & 0.4 \\
\hline RN14V2 & 830 & single & 11.12 & 9.6 & 0.3 \\
\hline RN15V2 & 780 & single & 10.90 & 9.8 & 0.6 \\
\hline RN16V2 & 730 & single & 12.25 & 10.7 & 0.9 \\
\hline RN17V2 & 700 & single & 12.88 & n.d. & \\
\hline
\end{tabular}

n.d. not determined - the composition of RN17V2 is outside the calibration range

a $\mathrm{H}_{2} \mathrm{O}$ added: $\mathrm{H}_{2} \mathrm{O}$ in the liquid phase calculated from the $\mathrm{H}_{2} \mathrm{O}$ added to the starting material as Al hydroxide or by micro-syringe taking into account modal proportions of liquid, amphibole and biotite

b $\mathrm{H}_{2} \mathrm{O}$ determined by Raman spectroscopy, the error associated with the calibration (standard) and fitting of the equation used to calculate the $\mathrm{H}_{2} \mathrm{O}$ contents amounts to approximately $0.5 \mathrm{wt} \%$

c Standard error $(2 \sigma)$ of the Raman spectroscopic measurements: 9 measurements ( 3 analyses per point, 3 different points) were averaged for every experiment listed 
Experimental setup

The fine-grained oxide, silicate, hydroxide starting material was dried at $110{ }^{\circ} \mathrm{C}$ before packed into the noblemetal containers. At temperatures exceeding $1,000{ }^{\circ} \mathrm{C}$, $\mathrm{Au}-\mathrm{Pd}$ alloys (90:10 ratio and 80:20 for some outer capsules) were employed as capsule material combined with the capsule-in-capsule technique (CICT; Kägi et al. 2005) (Electronic Supplementary Material ESM 1). Below $1,000{ }^{\circ} \mathrm{C}$, a single $\mathrm{Au}$ capsule was used assuming $\mathrm{Fe}$ loss to be less significant. The CICT resulted in negligible iron loss in the mass balance calculations, and Fe concentrations in the inner capsule walls were below the detection limit of the EPMA. The case of single Au capsules was somewhat different (e.g., Ratajeski and Sisson 1999): EPMA analyses of capsule walls resulted in very low iron contents and mass balance calculations were inappropriate as a $\mathrm{Fe}-\mathrm{Ti}$ oxide was always present. In this case, mass balance cannot be employed to evaluate potential iron loss, as this would simply be masked by increased calculated Fe-Ti oxide modal concentrations. $\mathrm{FeO}$ and $\mathrm{MgO}$ concentrations are rather low (MgO: 0.13-2.32 wt\%; $\mathrm{FeO}_{\text {tot }}: 0.30-4.22 \mathrm{wt} \%$ ) in these runs. The relative Fe loss has been up to $5 \%$ and resulted in somewhat increased $\mathrm{Mg \#}$ at lower temperatures as $\mathrm{MgO}$ concentrations were overestimated relative to $\mathrm{FeO}_{\text {tot }}$ concentrations (e.g., Ratajeski and Sisson 1999).

After tightly filling the capsules were weight, crimped, cut and welded shut using an arc welder. Sealing of the capsules was checked by weighting before and after welding by submersion in acetone. The capsules were embedded vertically in $\mathrm{MgO}-$ ceramic and contained in a $\mathrm{NaCl}$-pyrex-graphite-MgO piston cylinder assembly. The capsule was placed in the hotspot of the assembly, which was computed using the numerical model of Hernlund et al. (2006). All experiments were performed in a 14-mm bore end-loaded piston cylinder apparatus. A friction correction of $-3 \%$ was applied to the nominal pressure, based on calibrations employing the fayalite $+\mathrm{qtz}=$ orthoferrosilite univariant reaction at $1,000{ }^{\circ} \mathrm{C}$ and $1.41 \mathrm{GPa}$ (Bohlen et al. 1980) and the $\mathrm{qtz}=$ coesite transition at $1,000{ }^{\circ} \mathrm{C}$ and $3.07 \mathrm{GPa}$ (Bose and Ganguly 1995). The temperature was measured with a B-type $\mathrm{Pt}_{94} \mathrm{Rh}_{6} / \mathrm{Pt}_{70} \mathrm{Rh}_{30}$ thermocouple, with an estimated accuracy of $\pm 10{ }^{\circ} \mathrm{C}$. No corrections for the pressure effects on the electromotive force (emf) were performed. All runs were first pressurized to $0.4 \mathrm{GPa}$ at room temperature, then temperature increased to $550{ }^{\circ} \mathrm{C}$ and subsequently both pressure and temperature were increased concomitantly to the respective run conditions. The experiments were terminated by switching off the power supply resulting in quenching rates in excess of $100{ }^{\circ} \mathrm{C} / \mathrm{s}$.
Analytical methods

All recovered charges were embedded in epoxy resin, ground to expose a longitudinal section of the capsule(s) and polished with diamond paste down to 1 micrometer. For EPMA and SEM analyses, samples were coated with $20 \mathrm{~nm}$ of carbon.

\section{Electron probe micro-analyzer (EPMA)}

Experimental run products were analyzed with wavelength-dispersive spectrometers (WDS) on a JEOL JXA8200 electron probe micro-analyzer. An acceleration voltage of $15 \mathrm{kV}$ and a variable beam current and beam size (7 $\mathrm{nA}$ and 10-20 $\mu \mathrm{m}$ for glasses and $20 \mathrm{nA}$ and $1 \mu \mathrm{m}$ for minerals) were used to minimize alkali migration during analyses of hydrous glasses. Peak and background counting times were $20 \mathrm{~s}$. All data were corrected with the PRZ model (Goldstein et al. 1992; Korolyuk et al. 2009). For glasses, $\mathrm{H}_{2} \mathrm{O}$ was used as additional element for PRZ corrections and calculated as difference to $100 \mathrm{wt} \%$.

Modal proportions were calculated using non-weighted, least-squares regression (LSR) analyses implemented in Microsoft EXCEL ${ }^{\circledR} 2010$ balancing the nominal composition of the starting material against the averages of all analyzed phases in the experimental charges. Because FeTi oxide phases are overestimated using the LSR analyses in case of $\mathrm{Fe}$ loss to the noble-metal containers, backscattered electron (BSE) images of entire charges and an image processing program (ImageJ) were used to determine the modal proportions of iron oxide phases (Table 2).

\section{Micro-Raman spectroscopy}

The $\mathrm{H}_{2} \mathrm{O}$ contents of the recovered experimental glasses were quantified by micro-Raman spectroscopy. Raman scattering was excited using a 514.5-nm Ar Laser (Coherent Innova 90C), and measurements were performed with a Dilor Labram II confocal micro-Raman spectrometer. The laser beam was focused on the sample surface with a spot size of 1-2 $\mu \mathrm{m}$ in confocal mode. Spectra were obtained in the $180-1,500$ and $2,800-3,900 \mathrm{~cm}^{-1}$ range to cover low- and high-frequency $\mathrm{T}-\mathrm{O}$ stretching and vibration modes and the $\mathrm{OH} / \mathrm{H}_{2} \mathrm{O}$ stretching regions. Spectra were obtained by measuring 3 times the same spot and 3 different spots on each sample. For each spectrum, the acquisition time was $120 \mathrm{~s}$. The acquired spectra were post-processed using PeakFit ${ }^{\circledR}$ software employing a cubic baseline correction scheme similar to Di Muro et al. (2006) and Mercier et al. (2009). Quantification was obtained by acquiring Raman spectra of a total of 20 synthetic glasses with known $\mathrm{H}_{2} \mathrm{O}$ concentrations (Karl Fischer titration, KFT) ranging in composition from ol-tholeiite to rhyolite 


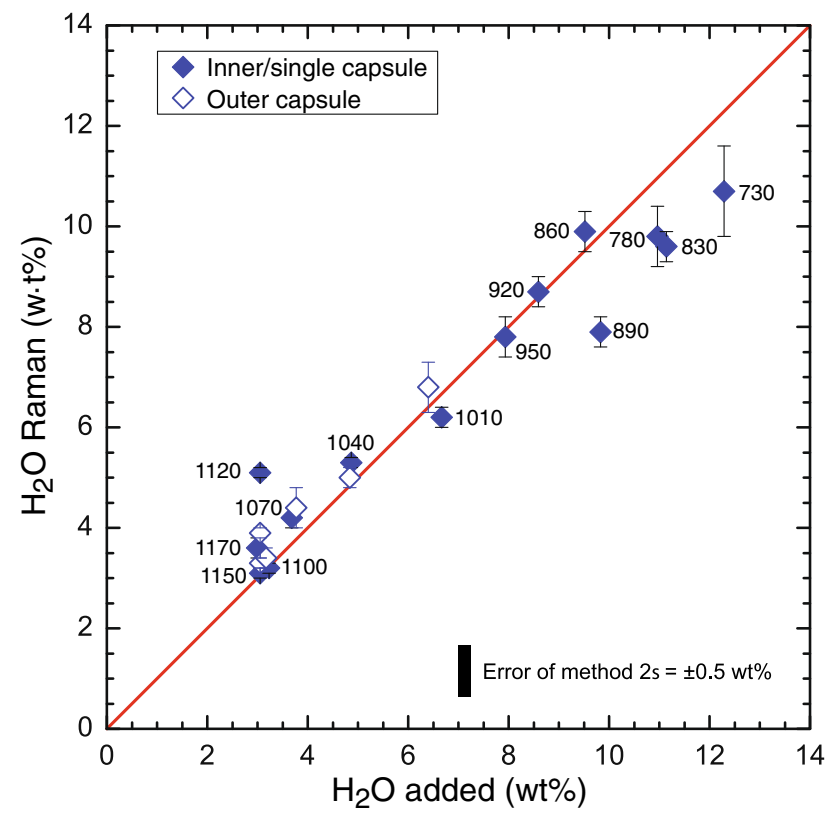

Fig. $1 \mathrm{H}_{2} \mathrm{O}$ contents determined by micro-Raman spectroscopy compared with $\mathrm{H}_{2} \mathrm{O}$ contents calculated from $\mathrm{H}_{2} \mathrm{O}$ added by hydroxides or by micro-syringe. " $\mathrm{H}_{2} \mathrm{O}$ added" corresponds to the amount of $\mathrm{H}_{2} \mathrm{O}$ in the liquid phase (glass) calculated from the amount of $\mathrm{H}_{2} \mathrm{O}$ in the capsule taking into account the modal proportions of liquid and amphibole. " $\mathrm{H}_{2} \mathrm{O}$ Raman" corresponds to the $\mathrm{H}_{2} \mathrm{O}$ content determined in the recovered glasses. Analyses are reported in Table 3

and $\mathrm{H}_{2} \mathrm{O}$ contents from 0.0 to $9.8 \mathrm{wt} \%$. The relative peak ratios of the $\mathrm{OH} / \mathrm{H}_{2} \mathrm{O}$ peak(s) to either the low(LF, $470-510 \mathrm{~cm}^{-1}$ ) or the high-frequency (HF, $980-1,140 \mathrm{~cm}^{-1}$ ) silicate vibration modes were calibrated as a function of $\mathrm{H}_{2} \mathrm{O}$ content and the $\mathrm{LF} / \mathrm{HF}$ ratio (as a proxy for composition or polymerization of the silicate glass). Two calibration curves were defined, one for the range ol-tholeiite to andesite and a second for andesite to rhyolite as no single, straightforward algorithm allowed fitting over the entire compositional range. Accuracy of the method is estimated at $\pm 0.5 \mathrm{wt} \% \mathrm{H}_{2} \mathrm{O}$, and results are reported in Table 3 and displayed in Fig. 1.

\section{Results}

Experimental conditions, phase assemblages, modes, relative $\mathrm{Fe}$ loss and estimated $\mathrm{fO}_{2}$ conditions are presented in Table 2. Average phase compositions with standard deviations, number of points and $\mathrm{Fe}-\mathrm{Mg}$ mineral-liquid exchange coefficients are reported in Table 4.

General remarks

The experiments reported in this study are fractional crystallization experiments performed over restricted temperature steps of mostly $30{ }^{\circ} \mathrm{C}$; at lower temperatures $\left(<830{ }^{\circ} \mathrm{C}\right)$, steps of $50{ }^{\circ} \mathrm{C}$ were used and two experiments (RN7W2 and RN8W2) were set between $30{ }^{\circ} \mathrm{C}$ steps, however, employing the same starting material as used for the respective lower-temperature experiments (RN7 and RN8, respectively) to explore phase relations, modes and compositions within steps that crystallized significant amounts of solids over a small temperature interval. All experiments produced large amounts of liquids (>74\%) facilitating analysis of the liquid phase using large electron beam sizes $(10-20 \mu \mathrm{m})$ and reduced currents $(7 \mathrm{nA})$ in order to minimize alkali migration in $\mathrm{H}_{2} \mathrm{O}$-rich glasses.

A prerequisite to successfully employ the capsule-incapsule technique to constrain the $\mathrm{fO}_{2}$ conditions via the ferric-ferrous iron ratio in the starting material is the preservation of a near-close system in particular regarding potential iron and hydrogen loss or gain. Iron loss was evaluated either directly via the least-squares regression (LSR) analysis of the experimental charges or by a combination of LSR and image analysis to quantify the amount of $\mathrm{Fe}-\mathrm{Ti}$ oxides independently (see above). The resulting iron loss was less than $6.5 \%$ relative for all but one higher temperature experiment (RN6, $1,070{ }^{\circ} \mathrm{C}$ ) that resulted $9.5 \%$. Fe loss of generally less than $5 \%$ is considered insignificant close to the statistically significant limit of the detection method, and, thus, we consider the experiment as (nearly) closed system regarding iron. Hydrogen loss (or gain) by diffusion through the noble-metal capsule will significantly influence the ambient $\mathrm{fO}_{2}$ conditions either reducing it through hydrogen gain or increasing it by loss to the outer capsule/assembly (Luth 1989). A general feature of all our experiments is the presence of vapor (fluid) bubbles (see Fig. 4) even at the highest temperature and relatively low $\mathrm{H}_{2} \mathrm{O}$ contents ( $3.0 \mathrm{wt} \%$, $\mathrm{RN} 1$ ), that become more frequent and generally larger with decreasing temperature and increasing $\mathrm{H}_{2} \mathrm{O}$ contents of the starting materials (up to $10.9 \mathrm{wt} \%$, RN 17V2). The solubility of pure $\mathrm{H}_{2} \mathrm{O}$ considerably exceeds the amounts of $\mathrm{H}_{2} \mathrm{O}$ added to the starting material as well as the amounts calculated for the residual liquids in the respective charges. At 0.7 $\mathrm{GPa}$, the solubility of $\mathrm{H}_{2} \mathrm{O}$ in basalts exceeds $8 \mathrm{wt} \%$ already at $0.5 \mathrm{GPa}$ (at the highest run temperature of $1,170{ }^{\circ} \mathrm{C}$ ) and exceeds $13 \mathrm{wt} \%$ at $700{ }^{\circ} \mathrm{C}$ for rhyolites for the same pressure (Newman and Lowenstern 2002; IaconoMarziano et al. 2012), whereas the nominally added $\mathrm{H}_{2} \mathrm{O}$ contents amount to $3 \mathrm{wt} \%$ for the initial basalt and 12.9 $\mathrm{wt} \%$ for the final rhyolite taking into account the liquid and hydrous phase proportions (amphibole and biotite) in lower-temperature runs. These values are considerably lower than the inferred solubility limits. The presence of bubbles is most likely caused by the presence of $\mathrm{CO}_{2}$ even though this was not verified to date. We attempted to avoid any potential $\mathrm{CO}_{2}$ contamination of the starting material 


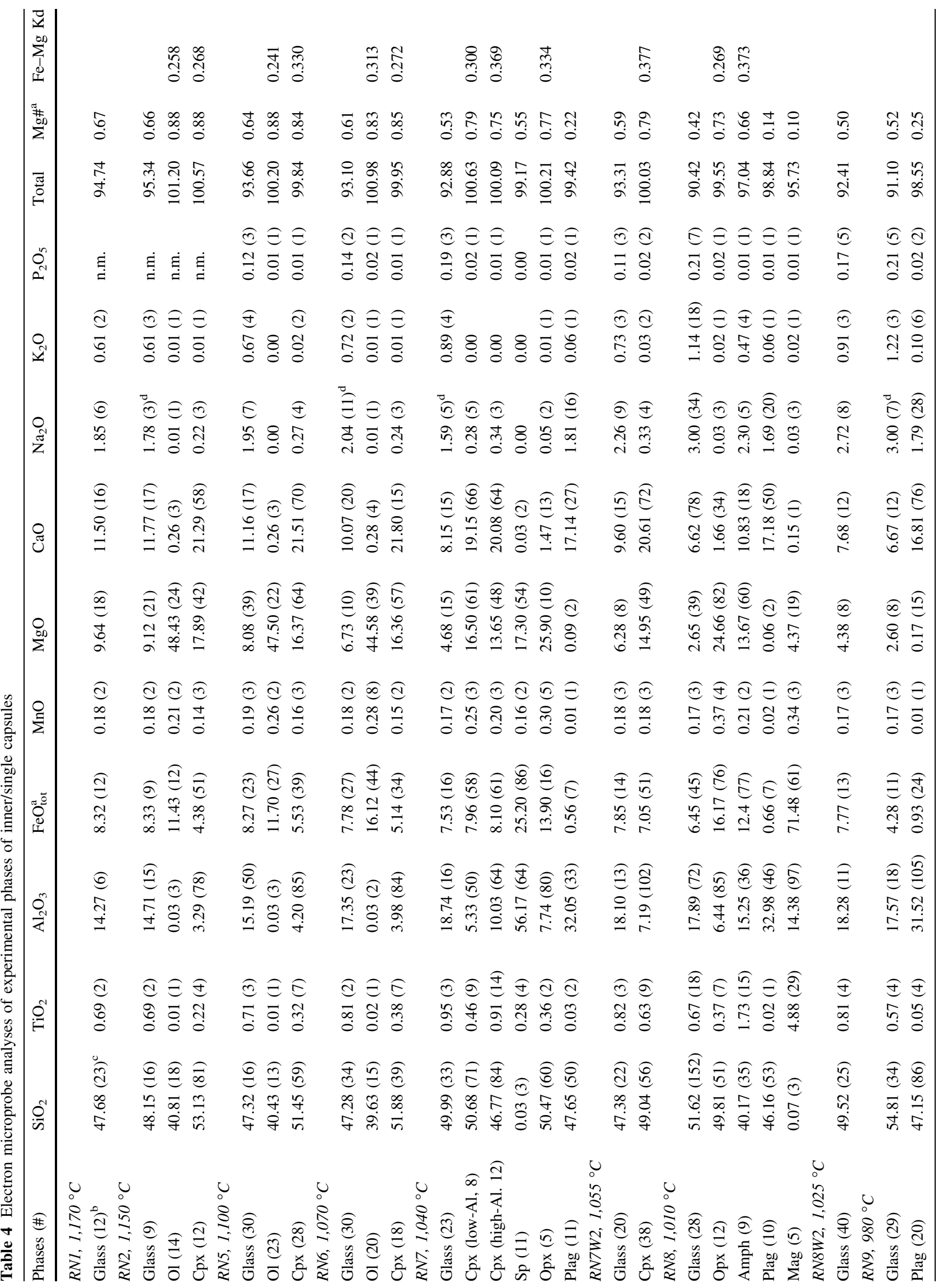




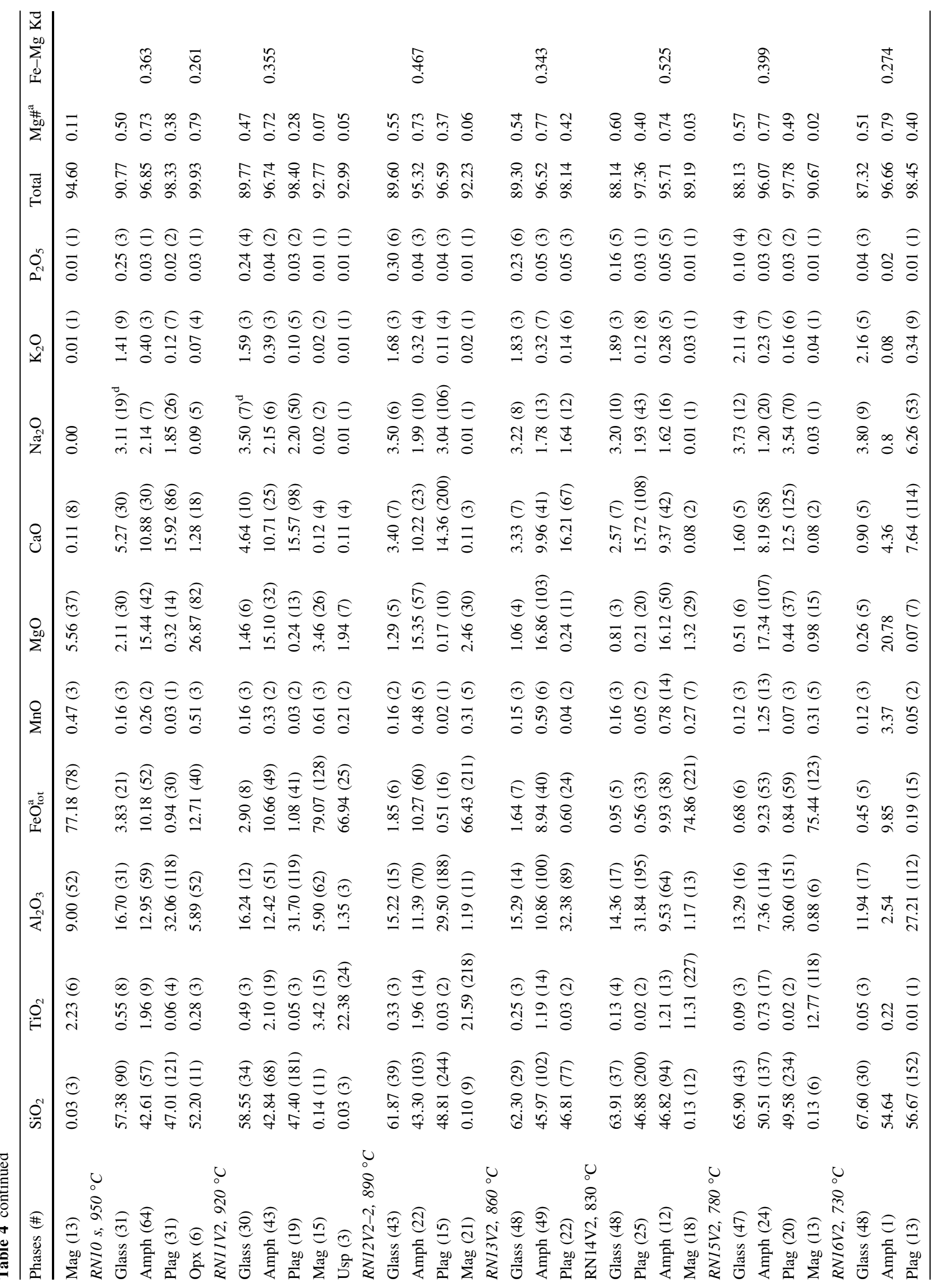




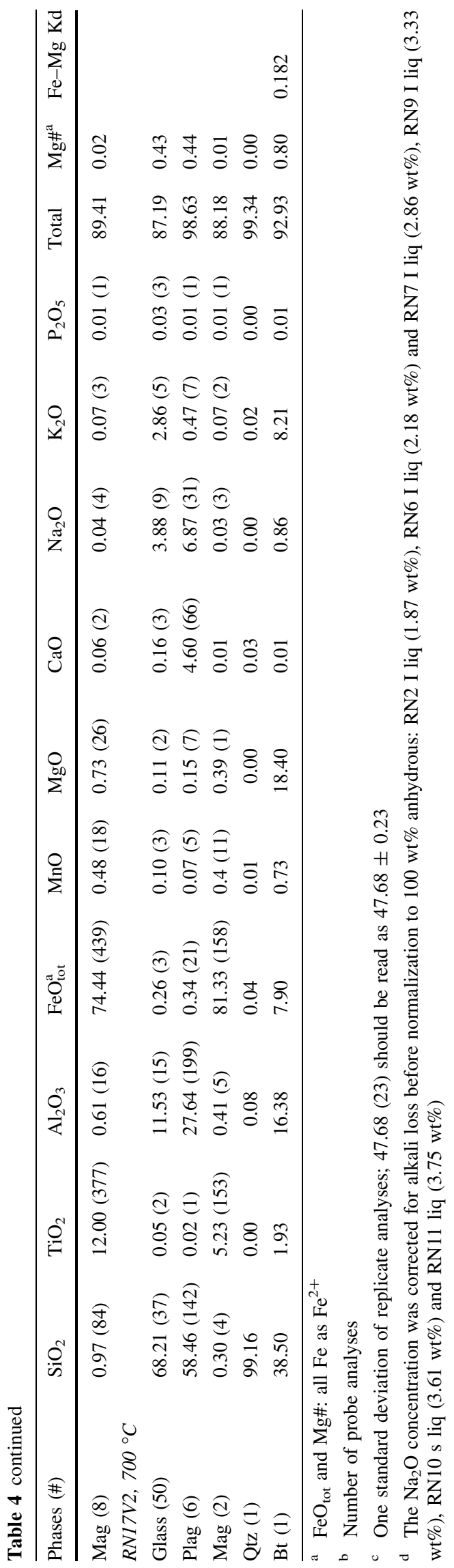

during preparation and welding by employing wollastonite, $\mathrm{Na}_{2} \mathrm{SiO}_{3}$ and $\mathrm{K}_{4} \mathrm{Si}_{5} \mathrm{O}_{12}$ as sources for $\mathrm{CaO}, \mathrm{Na}_{2} \mathrm{O}$ and $\mathrm{K}_{2} \mathrm{O}$ instead of commonly used carbonates and used a W-electrode instead of a graphite electrode for arc welding to prepare and shut the capsules. Figure 1 depicts the variation of the $\mathrm{H}_{2} \mathrm{O}$ contents calculated from the added amount of $\mathrm{H}_{2} \mathrm{O}$ in the starting material with the $\mathrm{H}_{2} \mathrm{O}$ content obtained by Raman spectroscopy and reveals a very consistent variation along a 1:1 correlation except for one run at $1,120{ }^{\circ} \mathrm{C}$ (RN4 not reported in Table 2, later repeated) and a possible deviation to lower but nearly constant values around $10 \mathrm{wt} \% \mathrm{H}_{2} \mathrm{O}$ at temperatures of $860{ }^{\circ} \mathrm{C}$ and less. The high value for run RN4 (5.1 wt\% Raman versus 3.04 wt $\%$ calculated) is fully consistent with the fact that this run did not crystallize any solids; therefore, it indeed contained too much $\mathrm{H}_{2} \mathrm{O}$ that was most likely introduced during preparation of the inner capsule. The upper limit of $\mathrm{H}_{2} \mathrm{O}$ contents around $10 \mathrm{wt} \%$ in the liquid is most probably the result of $\mathrm{CO}_{2}$ contamination limiting the amount of $\mathrm{H}_{2} \mathrm{O}$ soluble in the silicate liquid. A straightforward calculation of the minimum amount of $\mathrm{CO}_{2}$ that is required to saturate the experiments with a mixed $\mathrm{H}_{2} \mathrm{O}-\mathrm{CO}_{2}$ fluid using VolatileCalc (Newman and Lowenstern 2002, extrapolating beyond its nominal application range of 0.5 $\mathrm{GPa}$ ) results rather consistent values of about 3,500 ppm for the basaltic liquids at highest temperatures $\left(3 \mathrm{wt} \% \mathrm{H}_{2} \mathrm{O}\right.$, $1,150{ }^{\circ} \mathrm{C}$ ) and about the same amount (2,500-3,500 ppm) for rhyolitic liquids to limit the $\mathrm{H}_{2} \mathrm{O}$ solubility to $10 \mathrm{wt} \%$ in the liquid below $860{ }^{\circ} \mathrm{C}$. The exsolved fluid phase is $\mathrm{CO}_{2}$ rich for the basaltic to andesitic liquids $\left(\mathrm{xCO}_{2}>0.70\right)$ and becomes more hydrous $\left(\mathrm{xCO}_{2} \approx 0.5\right)$ for the felsic lowertemperature liquids. In summary, we clearly observe small amounts of vapor/fluid bubbles in all our charges that we attribute to uptake of $\mathrm{CO}_{2}$ by the very fine-grained oxidesilicate starting materials. However, the amount of calculated $\mathrm{CO}_{2}$ in our systems is small compared to the amount of $\mathrm{H}_{2} \mathrm{O}$ (always $<5 \mathrm{~mol} \%$ of the total volatile concentration), and we are, therefore, convinced that it does not significantly affect our phase relations, and mineral and liquid compositions. Overall the experiments were successful in maintaining the attempted $\mathrm{H}_{2} \mathrm{O}$ contents in our charges and neither gained nor lost significant amounts of hydrogen through diffusion through the noble-metal containers.

The approach to equilibrium in these experiments is facilitated by large liquid proportions always exceeding $74 \%$, very fine-grained starting materials $(<10 \mu \mathrm{m}$ grain size) and run durations that were optimized for equilibration versus iron and hydrogen loss that varied from $4 \mathrm{~h}$ at the highest temperatures to $168 \mathrm{~h}$ (1 week) at lowest temperatures close to the granite solidus. Elevated to high $\mathrm{H}_{2} \mathrm{O}$ concentrations further enhanced diffusional equilibration. Overheating of the starting materials to generate 
homogeneous liquids was avoided to circumvent the formation of metastable phases that are reluctant to dissolve and/or re-equilibrate at lower temperatures. Approach to equilibrium can be evaluated through the following considerations: (1) homogeneity of solid and liquid phases. For the liquid phase, 9-50 individual analyses were obtained from all experiments, with $>20$ analyses for all but the highest temperature experiments. Liquids were analyzed throughout the entire capsule, and we did not find any statistically significant variation throughout any of the capsules. Solid phases are generally homogeneous with two exceptions: (a) plagioclase reveals a significant variation in anorthite (An) content for most of the charges (see Fig. 8) with higher An contents for the larger and wellcrystallized crystals and lower An contents for small acicular to spherulitic plagioclase that most probably represent quench crystals. In addition, a few plagioclase crystals at lowest temperatures exhibit bright cores in BSE images representing residual corundum $\left(\mathrm{Al}_{2} \mathrm{O}_{3}\right)$ grains derived from the alumina oxide/hydroxide powders of the starting material (Fig. 2e) representing the only sign of incomplete reaction of starting materials observed; and (b) a single run produced sector-zoned clinopyroxene (cpx) with low-Al and high-Al sectors, a feature that is often observed in both experimental studies (e.g., Ulmer 1986; Sisson and Grove 1993a) and in field occurrences (e.g., Dessimoz et al. 2012; Hürlimann et al. 2014) in basaltic to andesitic systems and is not necessarily an expression of disequilibrium. (2) Textural observations summarized in Fig. 2 clearly reveal the presence of well-crystallized unzoned, idiomorphic solid phases in most but the lowest temperature experiments where plagioclase occasionally forms spherulitic aggregates that might either represent quench products or are related to delayed nucleation and rapid growth. (3) Major element partitioning, in particular $\mathrm{Fe}-\mathrm{Mg}$ (Table 4) is very consistent with values of 0.24-0.31 for olivine, $0.27-0.33$ for cpx (except the highAl cpx, 0.37), 0.27-0.30 for opx and 0.37-0.52 for amphibole (increasing with decreasing temperature). (4) Quench crystallization is very limited to some plagioclase and rare feathery overgrowth of cpx on stable crystals that are easily identified in BSE images. Large proportions of unmodified glass were present in all experiments. For mass balance calculations, compositions of inferred quench crystals were discarded and only the average compositions of the texturally stable minerals were considered.

The attainment of near constant $\mathrm{fO}_{2}$ at the intended value corresponding to the NNO equilibrium cannot be strictly validated. However, in all experiments that contained olivine, we evaluated the $\mathrm{fO}_{2}$ utilizing a combination of $\mathrm{Fe}^{2+}-\mathrm{Mg}$ partitioning assuming that olivine accommodates only ferrous iron and the known olivineliquid $\mathrm{Fe}^{2+}-\mathrm{Mg}$ partition coefficient as a function of pressure using the calibration of Ulmer (1989) that has been performed on basaltic liquids using starting materials from the same dike-rock association used for the current study with the same range of $\mathrm{H}_{2} \mathrm{O}$ contents resulting a $\mathrm{Fe}^{2+}-\mathrm{Mg}$ olivine-liquid partition coefficient of 0.317 . The amount of ferric iron was then estimated through a Monte Carlo type simulation taking into account the analytical uncertainty of the olivine and liquid compositions, and corresponding $\mathrm{fO}_{2}$ values were calculated using the algorithm of Kress and Carmichael (1991) relating ferric iron content of the liquid to liquid composition, temperature and pressure conditions (for detail of the method, see Kägi et al. 2005). The resulting $\mathrm{fO}_{2}$ varied between $\mathrm{NNO}$ and $\mathrm{NNO}+1.2$ for both inner and outer capsules in the temperature range $1,170-1,055^{\circ} \mathrm{C}$ (Table 2 ), testifying that a close approach to the targeted $\mathrm{fO}_{2}$ conditions could be achieved. As hydrogen diffusion and $\mathrm{Fe}$ loss presumably decrease with decreasing temperatures, we anticipate that $\mathrm{fO}_{2}$ conditions could be maintained close to or slightly above the NNO equilibrium.

\section{Phase relations and phase proportions}

The discussion of the phase relations and compositions is strictly limited to the results from the inner capsules in case of a double-capsule (CICT) setup as the outer capsule was generally made of alloys containing more $\mathrm{Pd}\left(\mathrm{Au}_{80} \mathrm{Pd}_{20}\right.$ instead of $\mathrm{Au}_{90} \mathrm{Pd}_{10}$ ) than used for the inner capsule leading to increased $\mathrm{Fe}$ loss in the outer capsule. In addition, the outer capsule was much larger and, thus, was subjected to a larger thermal gradient that in some cases resulted in the crystallization of additional phases at the extremities of the capsule. We provide the results obtained from the outer capsules as Electronic Supplementary Material (ESM Tables 1 and 2) as they are consistent or even equal the data obtained from the inner capsules in most cases.

Figure 3 provides a summary of the instantaneous solid compositions (ISC) rescaled to $100 \%$ and depicts the mineral phases and their modal proportions crystallizing in every fractionation step. The accumulated percentages of the crystalline fraction (total solid fraction, TSC) from the liquidus to the actual temperature are given in addition (Fig. 4). The liquidus temperature of the initial starting composition (RC 156) was bracketed at $1,160 \pm 5{ }^{\circ} \mathrm{C}$ with olivine as the liquidus phase. The second phase to crystallize together with olivine is high-Ca clinopyroxene (cpx, $1,100{ }^{\circ} \mathrm{C}$ and $1,070{ }^{\circ} \mathrm{C}$ ); at $1,055^{\circ} \mathrm{C}$, only clinopyroxene is present. At $1,040{ }^{\circ} \mathrm{C}$, plagioclase and hercynitic spinel crystallize concomitantly with clinopyroxene. It is noticeable that plagioclase crystallized before amphibole. At $1,010{ }^{\circ} \mathrm{C}$, amphibole and plagioclase with minor amounts of orthopyroxene and titanomagnetite form the solid assemblage that remains identical down temperature to 
Fig. 2 Back-scattered electron (BSE) images of representative experiments. a RN2-1,150 ${ }^{\circ} \mathrm{C}$; b $\mathrm{RN} 13 \mathrm{~V} 2-860{ }^{\circ} \mathrm{C}$;

c RN7 $-1,040{ }^{\circ} \mathrm{C}$; sector zoning in cpx; $\mathbf{d} \mathrm{Al}-\mathrm{K} \alpha \mathrm{X}$-ray

distribution map of sector-zoned cpx; e RN12V2-2-890 ${ }^{\circ} \mathrm{C}$;

f $\mathrm{RN} 10 \mathrm{~s}-950{ }^{\circ} \mathrm{C}$;

g RN17V2-700 ${ }^{\circ} \mathrm{C}$;

h RN17V2-2-700 ${ }^{\circ} \mathrm{C}$.

Abbreviations: Liq-liquid (glass), $\mathrm{Ol}$-olivine, $\mathrm{Cpx}-$ high-Ca clinopyroxene, Plagplagioclase, Amph — amphibole, Mag-titanomagnetite, Apapatite, Qtz-quartz, Btbiotite and Vap—vapor (bubble)
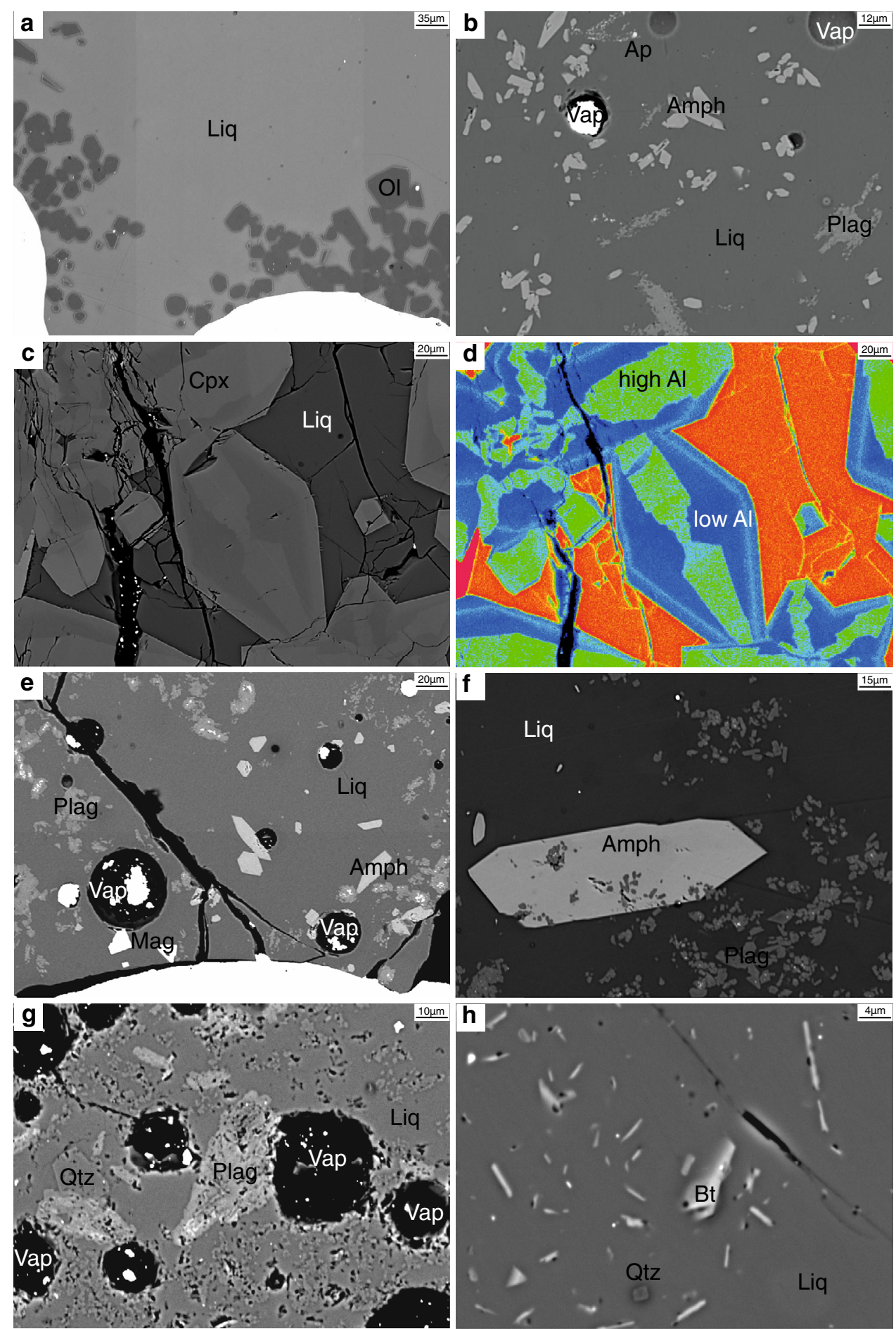

$730{ }^{\circ} \mathrm{C}$ except that orthopyroxene disappears below $950{ }^{\circ} \mathrm{C}$ and apatite joins the liquidus at $860{ }^{\circ} \mathrm{C}$. The experiment at $980{ }^{\circ} \mathrm{C}(\mathrm{RN}$ 9) failed to crystallize amphibole and orthopyroxene that are stable at $30{ }^{\circ} \mathrm{C}$ higher and lower temperature and only contained plagioclase and magnetite as solid phases. The exact reason for this inconsistency is not clear. However, the experimental setup only approaches near-perfect fractional crystallization, a temperature step of
$30{ }^{\circ} \mathrm{C}$ might leave the composition outside the stability field of some phases, but the crystallization of the stable phases, in this case plagioclase and magnetite, brings the derivative liquid ultimately back to the multiply saturated co- or peritectic curves resulting in the potential disappearance and reappearance of phases along the (incremental) experimental fractionation path. The large temperature interval from 1,010 to $730{ }^{\circ} \mathrm{C}$ produces hornblende gabbroic to 
Fig. 3 Modal proportions (wt\%) of solid phases in each experiment (correspond to the instantaneous solid composition (ISC)) normalized $100 \mathrm{wt} \%$.

Labels on the top indicate the absolute fraction (wt\%) of solids crystallized in the experiments
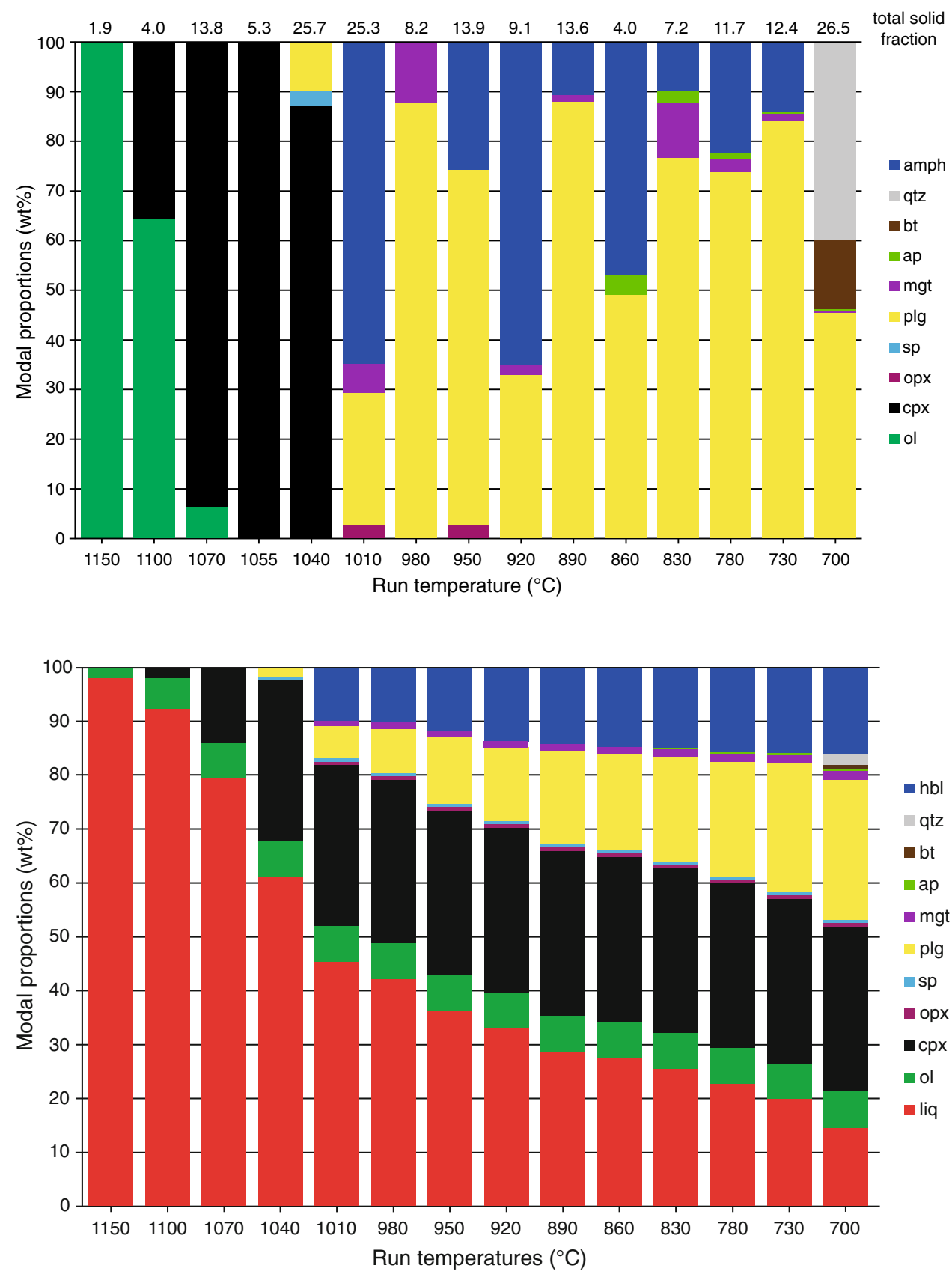

Run temperatures $\left({ }^{\circ} \mathrm{C}\right)$
Fig. 4 Total solid composition (TSC) summarizing the modal proportions of solid phases accumulated relative to the initial olivine-tholeiitic starting composition. Intermediate step experiments at 1,055 and $1,025{ }^{\circ} \mathrm{C}$ have been omitted dioritic cumulate rocks containing minor amounts of orthopyroxene, Fe-Ti oxide (titanomagnetite to ulvöspinel) and apatite. The last fractional step produced a high-silica rhyolite liquid coexisting with plagioclase, quartz, biotite, titanomagnetite and apatite. Temperature steps with most extensive crystallization occur between 1,070 and $1,010{ }^{\circ} \mathrm{C}$ and below $730{ }^{\circ} \mathrm{C}$. In the range $1,040-1,010{ }^{\circ} \mathrm{C}$, two important changes in the phase relations are observed: (1) The most likely cotectic reaction where plagioclase joins the liquidus together with cpx and hercynitic spinel and (2) a peritectic reaction just above $1,010{ }^{\circ} \mathrm{C}$ where amphibole + orthopyroxene join the liquidus and replace clinopyroxene. At $700{ }^{\circ} \mathrm{C}$, the temperature of the granite eutectic is approached where the remaining liquid is inferred to crystallize over a small temperature interval and where K-feldspar should join the crystallizing assemblage that is composed of quartz, albite-rich plagioclase, biotite and apatite inferring another peritectic reaction where amphibole reacts with liquid to biotite terminating the crystallization interval of amphibole to lower temperature.

Figure 4 illustrates the total solid composition (TSC) representing the accumulated modal proportions of crystallized phases relative to the initial liquid (RC156). This diagram highlights the absolute amount of residual liquid 
left after each fractionation step. A total of 35-40\% of ultramafic cumulates composed of dunites, wehrlites and (olivine- or plagioclase-) clinopyroxenites are extracted before gabbroic cumulate compositions occur. A total of $60 \%$ cumulates are required to be extracted to obtain an andesitic $\left(60 \mathrm{wt} \% \quad \mathrm{SiO}_{2}\right)$ liquid at $980{ }^{\circ} \mathrm{C}$. Only $20 \%$ additional cumulates are formed between 980 and $730{ }^{\circ} \mathrm{C}$, an interval of $250{ }^{\circ} \mathrm{C}$ to derive rhyolitic liquids; a somewhat unexpected result that has considerable consequences for the rheologic behavior of andesitic magmas in the Earth's crust, which is addressed in the discussion.

Phase compositions

\section{Liquid}

The proportions of the liquid phase present as quenched glasses were consistently high and exceeded $74 \%$ in all experiments. For comparison and discussion, the liquid compositions were normalized to $100 \%$ anhydrous and presented as a function of temperature in Fig. 5. The silica content is initially $\left(1,170-1,055{ }^{\circ} \mathrm{C}\right)$ constant around $51 \mathrm{wt} \%$ and then increases abruptly at $1,040{ }^{\circ} \mathrm{C}$ followed by a continuous increase without any gaps to $79 \mathrm{wt} \%$ in the interval 1,025 to $700{ }^{\circ} \mathrm{C}$. Evaluation of the extracted phase assemblages (Fig. 3) reveals that the onset of the pronounced silica increase is due to the crystallization of $3 \mathrm{wt} \%$ hercynitic spinel and $10 \mathrm{wt} \%$ anorthite-rich plagioclase. The subsequent continuous increase in silica is related to the formation of amphibole, plagioclase and minor titanomagnetite and, at higher temperature, some orthopyroxene. The final value of $79 \mathrm{wt} \% \mathrm{SiO}_{2}$ coincides with the precipitation of quartz + biotite. The saturation temperatures of clinopyroxene and plagioclase are best appreciated by inspecting the $\mathrm{CaO}$ and $\mathrm{Al}_{2} \mathrm{O}_{3}$ variation diagrams (Fig. 5b and d). The bend in $\mathrm{CaO}$ concentration with decreasing temperature reflects the early $\left(>1,100{ }^{\circ} \mathrm{C}\right)$ crystallization of clinopyroxene, and the bend in $\mathrm{Al}_{2} \mathrm{O}_{3}$ concentration around $1,050{ }^{\circ} \mathrm{C}$ coincides with the crystallization of plagioclase. The concentrations of $\mathrm{Na}_{2} \mathrm{O}$ and $\mathrm{K}_{2} \mathrm{O}$ in the liquid (Fig. 5f and h) increase with decreasing temperature; they behave incompatible and are concentrated in the liquid throughout all the experiments. This is not perfectly true for $\mathrm{Na}_{2} \mathrm{O}$ as this oxide is included in plagioclase and amphibole, but the bulk incompatible behavior leads to an increase in the liquid with decreasing temperature. Kinks in the $\mathrm{TiO}_{2}$ and $\mathrm{P}_{2} \mathrm{O}_{5}$ concentrations (Fig. 5c and j) mark the onset of titanomagnetite and apatite crystallization at 1,010 and $860{ }^{\circ} \mathrm{C}$, respectively. Iron oxide and magnesia concentrations (Fig. 5e and i) decrease with decreasing temperatures except for the highest temperature experiments where $\mathrm{FeO}_{\text {tot }}$ concentrations remain nearly constant until a spinel phase (hercynite) joins the crystallizing assemblage. The calculated $\mathrm{Mg}$-number is monotonically decreasing until $1,010{ }^{\circ} \mathrm{C}$ and undulates toward lower temperature. We attribute this unusual behavior to the fact that Fe loss was (initially) underestimated, and therefore, the subsequent starting materials contained too low $\mathrm{FeO}_{\text {tot }}$ concentration. The effect of this minor shortcoming on the phase equilibria is, however, most likely negligible as all experiments concerned are Fe-Ti oxide saturated and the total amount of $\mathrm{FeO}+\mathrm{MgO}$ is rather low. $\mathrm{MnO}$ concentrations (Fig. 5g) remain constant until $900{ }^{\circ} \mathrm{C}$ and decrease thereafter. $\mathrm{H}_{2} \mathrm{O}$ concentrations in the residual liquids (Fig. 1) increase continuously from 3 to $10 \mathrm{wt} \%$ down to $860{ }^{\circ} \mathrm{C}$ and scatter around $10 \mathrm{wt} \%$ for the lowest temperatures either due to limited solubility caused by the presence of $\mathrm{CO}_{2}$ or inability of the Raman method to accurately determine $\mathrm{H}_{2} \mathrm{O}$ contents exceeding $10 \mathrm{wt} \%$.

\section{Olivine}

Olivine occurred in the range $1,150-1,070{ }^{\circ} \mathrm{C}$, and its composition decreased from Fo 88.0 to 82.5 . The $\mathrm{Ca}$ content of olivine is consistently low and varies between 0.24 and $0.31 \mathrm{wt} \% \mathrm{CaO}$.

\section{Clinopyroxene}

Clinopyroxene (cpx) crystallized over a wider temperature range $\left(1,170-980^{\circ} \mathrm{C}\right)$ in the outer capsule than in the inner capsule $\left(1,100-1,040{ }^{\circ} \mathrm{C}\right)$. Crystallization of cpx additionally occurred during quench generating overgrowth rims in the form of feathery crystals on cpx that grew in equilibrium with the liquid during the experiment. The compositions of quench crystals are not considered here. All cpx from outer and inner capsules display a positive correlation of Ti versus tetrahedrally coordinated $\mathrm{Al}\left(\mathrm{Al}^{\mathrm{IV}}\right.$, Fig. 6a) constraining $\mathrm{Ti}$ incorporation via the exchange $\mathrm{TiAl}^{\mathrm{IV}} \mathrm{Al}^{\mathrm{IV}}=(\mathrm{Mg}$, $\left.\mathrm{Fe}^{2+}\right)$ SiSi. Similarly, Mg displays a negative correlation with $\mathrm{Al}^{\mathrm{IV}}$, testifying that the principal exchange controlling Al incorporation in cpx is the Tschermak's vector $\left(\left(\mathrm{Mg}, \mathrm{Fe}^{2+}\right) \mathrm{Si}=\mathrm{Al}^{\mathrm{VI}} \mathrm{Al}^{\mathrm{IV}}\right)$; Fig. 6c). Aluminum variation as a function of temperature (Fig. 6b) reveals several features: (1) At $1,040{ }^{\circ} \mathrm{C}$, two distinct cpx compositions are present-one with high-Al contents $\left(8-10\right.$ wt $\% \mathrm{Al}_{2} \mathrm{O}_{3}$, high $\mathrm{Ti}$ and low $\mathrm{Mg}, \mathrm{Si}$ ) and one with low $\mathrm{Al}$ (4.5-5.5 wt\% $\mathrm{Al}_{2} \mathrm{O}_{3}$, low $\mathrm{Ti}$, high $\mathrm{Si}, \mathrm{Mg}$ ) denoted as low- and high-Al cpx, respectively. This is not an uncommon observation in experimental and natural systems (e.g., Villiger et al. 2004; Whitaker et al. 2008; Dessimoz et al. 2012) and represents either the expression of a stable solvus in the diopsideTschermak's pyroxene system or, alternatively, a metastable phenomena that is not strictly limited to experimentally grown cpx in hydrous calc-alkaline systems, but likewise occurs in natural rocks ranging from plutonic (gabbroic) to hypabyssal (dike rocks) with commonly the low-Al cpx 
Fig. 5 Concentrations of major and minor oxides of the liquid (glass) phase (normalized anhydrous to $100 \mathrm{wt} \%$ ) as a function of temperature

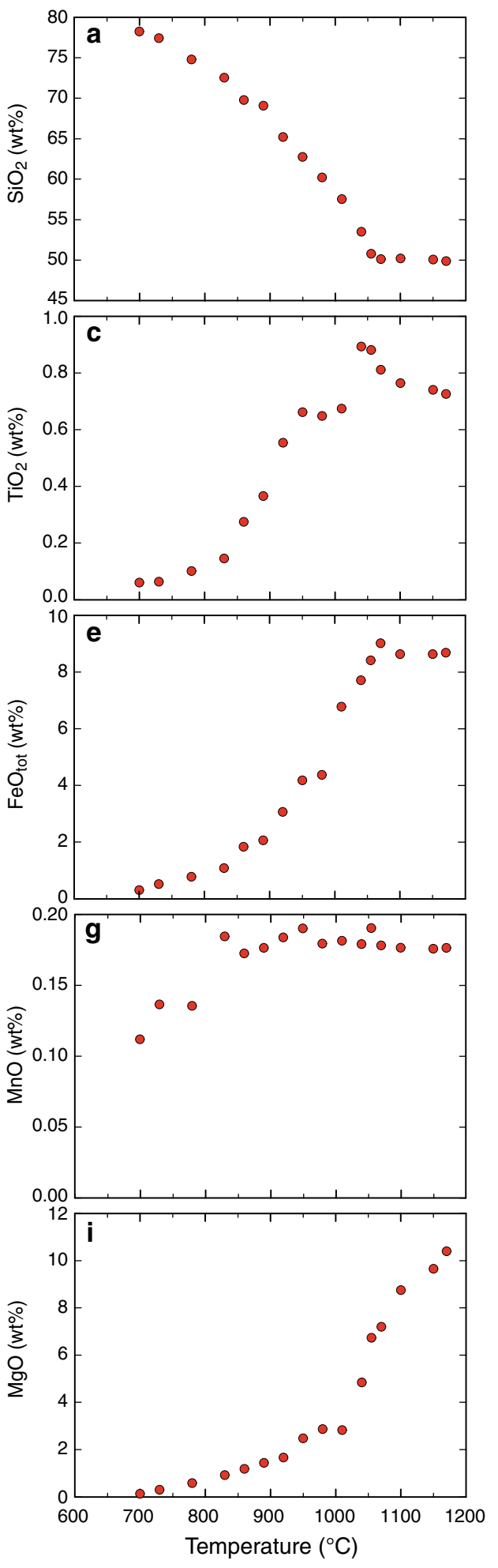

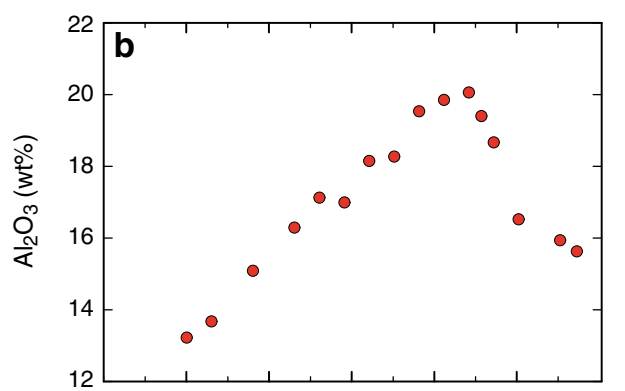
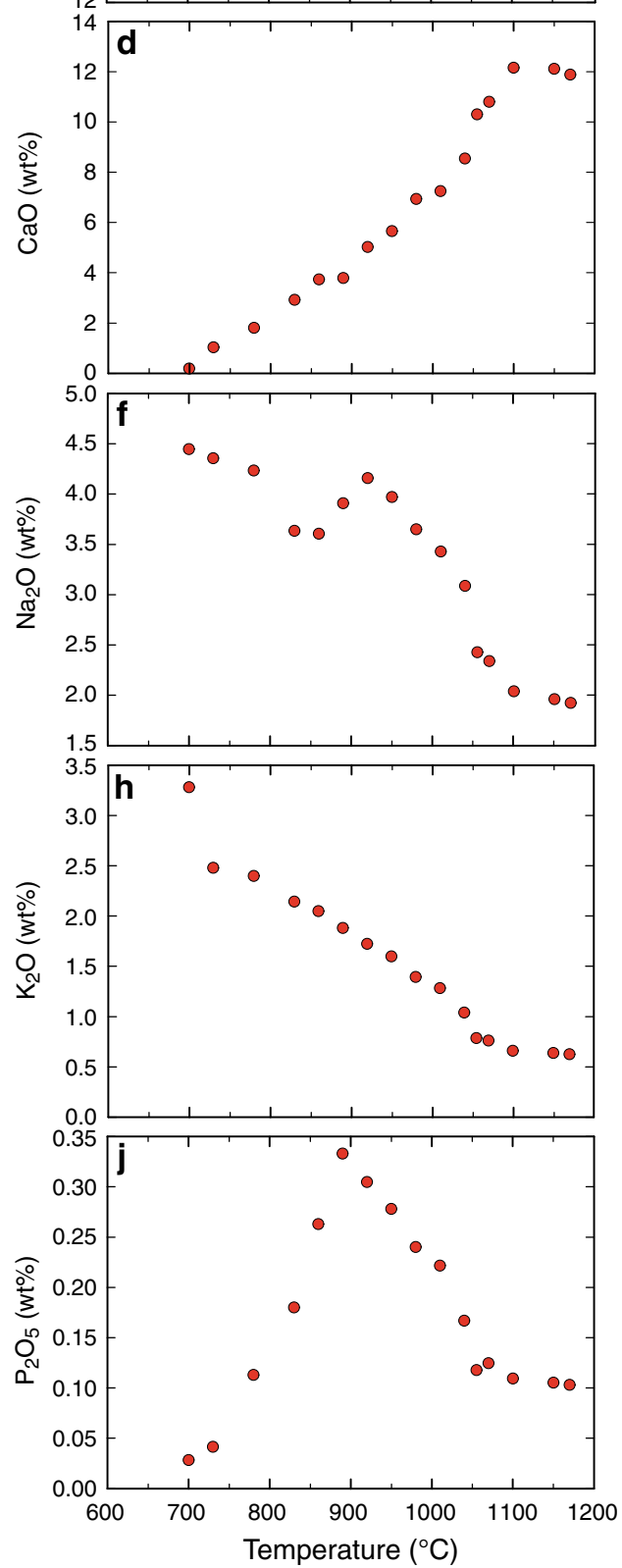

forming either the core of a zoned clinopyroxene (the rim being high-Al cpx) or occurring as sector-zoned cpx as shown in Fig. 2c and d (Sisson and Grove 1993a; Kawamoto 1996). (2) A conspicuous jump in Al concentration around $1,050{ }^{\circ} \mathrm{C}$ from lower to higher values that coincides with plagioclase saturation of the coexisting liquid is evident and is most likely due to increasing $\mathrm{Al}$ activity in the melt phase (see Villiger et al. 2007 and references therein). The magnesium content of cpx (Fig. 6d) decreases with decreasing temperature, again changing abruptly, when plagioclase saturates, inversely correlating with increasing Tschermak's component. 

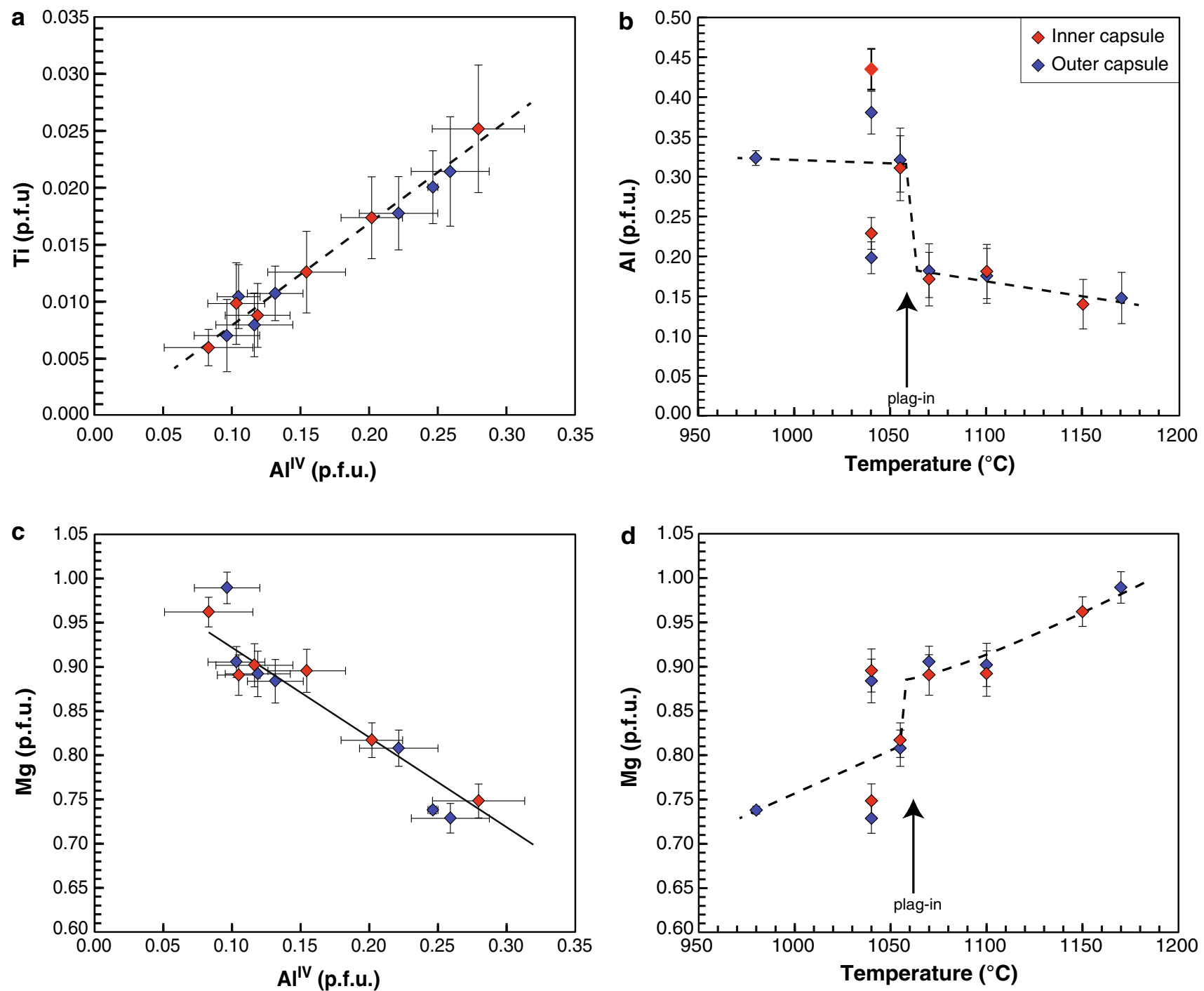

Fig. 6 Compositions of clinopyroxene as a function of $\mathrm{Al}^{\mathrm{IV}}(\mathbf{a}, \mathbf{b})$ and temperature (c,d). Cations per formula unit (p.f.u.) were calculated on the basis of 4 cations and 12 positive charges

\section{Orthopyroxene}

The temperature range of orthopyroxene crystallization is rather narrow $\left(1,040-950{ }^{\circ} \mathrm{C}\right)$. $\mathrm{Ca}, \mathrm{Ti}$ and $\mathrm{Al}$ contents decrease with decreasing temperature; the same is true for the Mg-number except for the lowest temperature run $\left(\mathrm{RN} 10 \mathrm{~s}, 950{ }^{\circ} \mathrm{C}\right.$ ) that showed higher Mg\# for orthopyroxene consistent with the higher $\mathrm{Mg \#}$ of the bulk system and the liquid phase.

\section{Amphibole}

Amphibole crystallized over a wide temperature range $\left(1,010-730{ }^{\circ} \mathrm{C}\right)$. The crystals become generally smaller with decreasing temperature (Fig. 2b, e and f). Amphibole compositions have been normalized using a normalization scheme (Spear and Kimball 1984) based on charge balance (46 positive charges without $\mathrm{OH}, \mathrm{F}, \mathrm{Cl}$ ) and an empirically fixed ferric to total iron ratio $\left(\mathrm{Fe}^{3+} / \mathrm{Fe}_{\text {tot }}\right)$ of 0.33 . Compositions of amphiboles span from pargasite at high temperature in basaltic-andesite liquids to magnesiohornblende in andesitic liquids to cummingtonite at the lowest temperature $\left(730{ }^{\circ} \mathrm{C}\right)$ coexisting with a rhyolitic liquid. The silica content of the amphiboles monotonically increases with decreasing temperature from 5.9 to nearly 7.8 cations p.f.u. The aluminum concentration behaves opposite and decreases with decreasing temperature from 2.64 to 0.68 cations p.f.u. (Fig. 7a). The calculated tetrahedrally coordinated aluminum $\left(\mathrm{Al}^{\mathrm{IV}}\right)$ decreases strongly with temperature, whereas the octahedrally coordinated aluminum $\left(\mathrm{Al}^{\mathrm{VI}}\right)$ concentration remains nearly constant. Magnesium concentrations increase while iron concentrations remain 

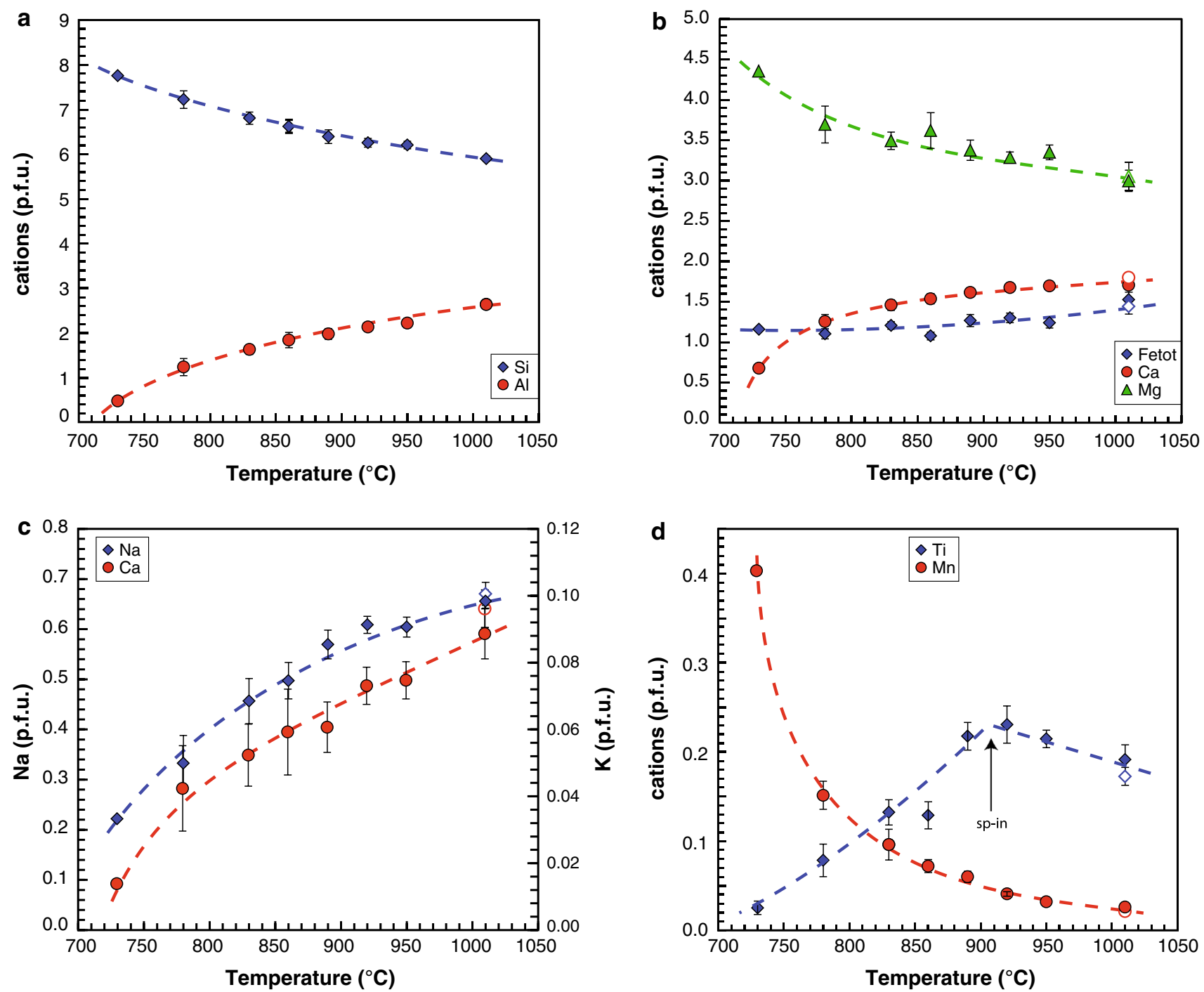

Fig. 7 Composition of amphibole as a function temperature. Cations per formula (p.f.u.) unit were calculated on the basis of 46 positive charges (excluding $\mathrm{H}$ ) and normalized with a fixed $\mathrm{Fe}^{3+} / \mathrm{Fe}_{\text {tot }}$ of 0.33

nearly constant with temperature (Fig. 7b). Calcium, Na and $\mathrm{K}$ concentrations (Fig. $7 \mathrm{~b}$ and $\mathrm{c}$ ) all decrease with decreasing temperature reflecting decreasing edenite and tschermakite and increasing cummingtonite components with decreasing temperature. Titanium slightly increases until $920^{\circ} \mathrm{C}$, and then, the trend inverts (Fig. 7d); this coincides with the onset of Ti-rich magnetite to ulvöspinel co-precipitating with amphibole strongly depleting the residual liquid in $\mathrm{TiO}_{2}$. With decreasing temperature, $\mathrm{Mn}$ (Fig. 7d) is incorporated exponentially in amphibole and most probably leads to the stabilization of cummingtonite amphibole at lowest temperature.

\section{Feldspar}

Plagioclase crystallized from 1,040 to $700{ }^{\circ} \mathrm{C}$. The common crystal habits are laths-shaped. Their size decreases with decreasing temperature, and they have a tendency to form glomerocrysts (Fig. 2b, e-g). Overall, the anorthite content decreases toward lower temperatures from an average $\mathrm{An}_{85}$ to $\mathrm{An}_{27}$ but some runs exhibit rather large variations within the plagioclase population (Fig. 8a) probably due (1) early plagioclase growth around refractory corundum grains producing high An-plagioclase and (2) as evident in the microstructures, late plagioclase microlites related to quench crystallization. It is, therefore, not straightforward to determine the stable, equilibrium plagioclase composition. We prefer an overall evolution as depicted with the dashed line in Fig. 8a. Potassium concentrations remain nearly constant until $840{ }^{\circ} \mathrm{C}$ and increase thereafter to reach $0.47 \mathrm{wt} \%$ at $700{ }^{\circ} \mathrm{C}$ (Fig. 8b) concomitant with the strong decrease in An content and increase in $\mathrm{K}_{2} \mathrm{O}$ of the coexisting liquid in the same temperature interval. 

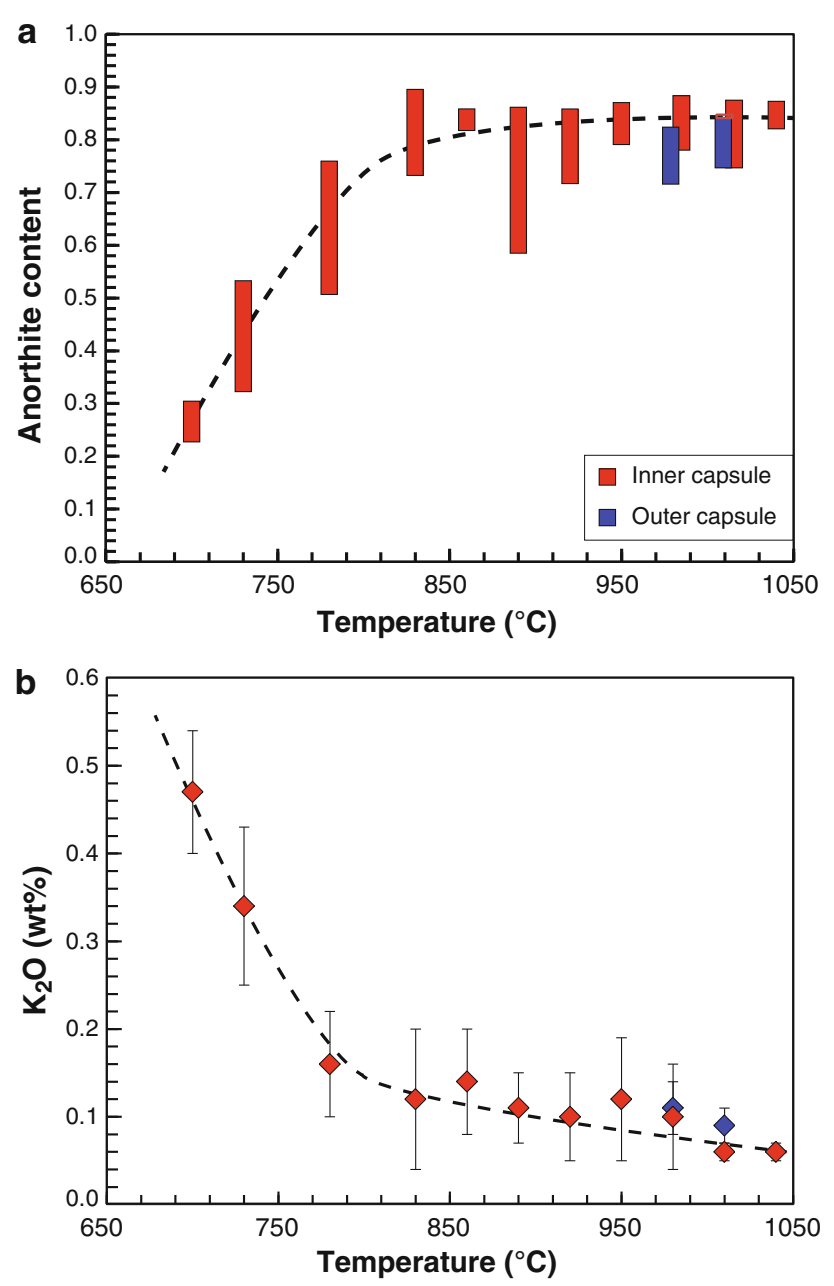

Fig. 8 Anorthite (An) content (a) and $\mathrm{K}_{2} \mathrm{O}$ (wt $\%$ ) concentrations (b) of plagioclase feldspar as a function of temperature. Dashed line represents the preferred evolution of the An content with temperature excluding quench microlites and high-An cores related to unreacted $\mathrm{Al}_{2} \mathrm{O}_{3}$ oxide in the starting material

\section{Iron-titanium oxides (spinels)}

Various $\mathrm{Fe}-\mathrm{Mg}-\mathrm{Al}-\mathrm{Ti}$ cubic oxides crystallized in the experiments. In the absence of any $\mathrm{Cr}$ in the system, the first spinel phase to saturate was hercynitic spinel with 46-56 wt $\% \mathrm{Al}_{2} \mathrm{O}_{3}, 25-38 \mathrm{wt} \% \mathrm{FeO}_{\text {tot }}$ and $14-17 \mathrm{wt} \%$ $\mathrm{MgO}$ at $1,040{ }^{\circ} \mathrm{C}$, followed by $\mathrm{Ti}-\mathrm{Al}-\mathrm{Mg}$-bearing magnetite at 1,010 and $980{ }^{\circ} \mathrm{C}$. At $920{ }^{\circ} \mathrm{C}$, two coexisting spinels $\mathrm{Ti}-\mathrm{Al}-\mathrm{Mg}$-bearing magnetite $\left(3.4 \mathrm{wt} \% \mathrm{TiO}_{2}\right)$ and an ulvöspinel $\left(22.4 \mathrm{wt} \% \mathrm{TiO}_{2}\right)$ were observed. With decreasing temperatures, titanomagnetite becomes less $\mathrm{TiO}_{2}$ rich, and finally at $700{ }^{\circ} \mathrm{C}$, a Fe-rich Ti-bearing, $\mathrm{Al}$ - and $\mathrm{Mg}$-poor magnetite $\left(5.2 \mathrm{wt} \% \mathrm{TiO}_{2}\right)$ is stable close to the solidus. Additional information on the compositional variations of spinels among the spinel phases as a function of temperature is provided as ESM 2.
Apatite

Apatite crystallized in experiment at temperatures less than $890{ }^{\circ} \mathrm{C}$ as is clearly testified by the kink in the $\mathrm{P}_{2} \mathrm{O}_{5}$ versus temperature curve (Fig. 5j). Apatite was visible in BSE images (Fig. 2b) and characteristic X-ray distribution maps (P-K $\alpha$ maps) in all runs below $890{ }^{\circ} \mathrm{C}$, but the grains were too small to obtain reliable microprobe analysis. For estimation of the modal fractions of apatite by least-square regression, an ideal apatite composition has been used.

\section{Biotite}

Biotite crystallized in the lowest temperature step investigated $\left(700^{\circ} \mathrm{C}\right)$. The late occurrence of biotite on the liquidus might have two main reasons: (1) The compositions investigated in this study (Fig. 10) belong to a medium-K calc-alkaline series, and only at $700{ }^{\circ} \mathrm{C}$, the $\mathrm{K}_{2} \mathrm{O}$ concentration $(2.37 \mathrm{wt} \%)$ might be high enough to saturate a potassic phase and (2) performing near-perfect fractional crystallization experiments might delay biotite saturation by efficient removal of $\mathrm{Fe}$ and $\mathrm{Mg}$ generating rhyolitic liquids. Analyses of thin biotite laths were rather difficult as they rarely exceeded $1 \mu \mathrm{m}$ in thickness (Fig. $2 \mathrm{~h}$ ). Therefore, the reported biotite analyses (run RN17) should be considered indicative rather than precise.

\section{Quartz}

Quartz crystallized in the last fractionation step together with biotite, plagioclase, magnetite and apatite when the $\mathrm{SiO}_{2}$ concentration in the liquid reached $79 \mathrm{wt} \%$. Crystals are idiomorphic and most of them less than $1 \mu \mathrm{m}$ in size (Fig. 2g). Due to their idiomorphic shape, it can be excluded that they represent non-reacted $\mathrm{SiO}_{2}$ from the starting material.

\section{Discussion}

Comparison of liquid compositions with previous studies

The first part of the discussion presents a comparison of the experimentally derived liquid compositions of this study with those from previous studies on hydrous calc-alkaline and anhydrous (tholeiitic) differentiation at a pressure of $0.7 \mathrm{GPa}$.

In order to distinguish the tholeiitic from the calcalkaline differentiation series, the AFM diagram of Wager and Deer (1939) (Fig. 9) with discrimination lines according to Kuno (1968) and Irvine and Baragar (1971) was utilized. The liquid compositions of this study clearly 


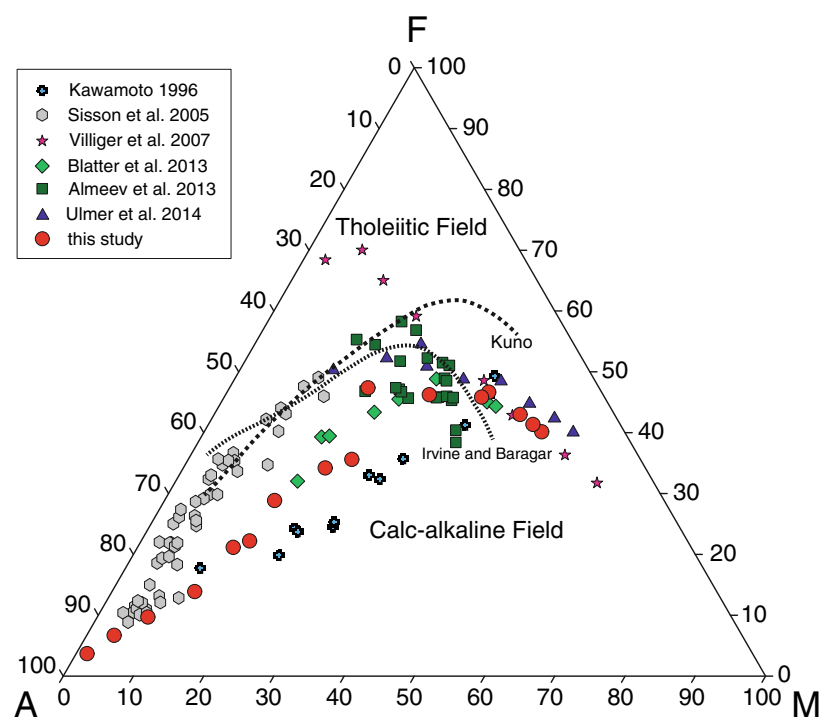

Fig. 9 AFM $\left(A=\mathrm{Na}_{2} \mathrm{O}+\mathrm{K}_{2} \mathrm{O}, \mathrm{F}=\mathrm{FeO}, \mathrm{M}=\mathrm{MgO}\right.$; wt $\left.\%\right)$ diagram discriminating tholeiitic and calc-alkaline magmatic series. Separation lines according to Kuno (1968) and Irvine and Barager (1971). Data sources and experimental conditions: Kawamoto (1996) — high-alumina basalt, $2 \mathrm{wt} \% \mathrm{H}_{2} \mathrm{O}$, equilibrium crystallization, $\mathrm{NNO}+1.3,0.5 \mathrm{GPa}$; Sisson et al. (2005)—basalt, 1.7-2.3 wt\% $\mathrm{H}_{2} \mathrm{O}$, equilibrium crystallization, $\mathrm{NNO}-1.3$ to $+4,0.7 \mathrm{GPa}$; Villiger et al. (2007) - ol-tholeiite, anhydrous, fractional crystallization, C- $\mathrm{CO}_{2}$, $0.7 \mathrm{GPa}$; Blatter et al. (2013)- $\mathrm{Mg}-$ basalt, $2.1 \mathrm{wt} \% \mathrm{H}_{2} \mathrm{O}$, equilibrium crystallization, $\mathrm{Re}-\mathrm{ReO}_{2}, 0.7 \mathrm{GPa}$; Almeev et al., (2013)-basaltic andesite, 3.8-10.7 wt $\% \mathrm{H}_{2} \mathrm{O}$, equilibrium crystallization, FMQ +2.7 - FMQ +4.1, 0.7 GPa; Ulmer et al. (2014)—picrobasalt, 2.6 wt $\% \mathrm{H}_{2} \mathrm{O}$, fractional crystallization, $\mathrm{NNO}+0.4,1.0 \mathrm{GPa}$

follow a calc-alkaline trend. This is distinctly different from the study of Villiger et al. (2007) showing enrichment in iron and, therefore, follows a tholeiitic trend. It should be noted that both studies have a comparable initial liquid composition. Villiger et al. (2007) conducted anhydrous fractionation experiments under more reducing conditions (graphite-saturated), and this study simulates hydrous fractional crystallization at $\mathrm{fO}_{2}$ conditions close to the NNO equilibrium. Our results are consistent with other studies in hydrous systems (Kawamoto 1996; Sisson et al. 2005; Almeev et al. 2013; Blatter et al. 2013) that follow a calc-alkaline trend. The starting compositions of those studies are somewhat different than the one employed in this study ranging from basaltic to basaltic andesitic (Sisson et al. 2005) to high-alumina basalt (Kawamoto 1996). Sisson and Grove (1993b) showed that high-alumina basalt can be reached by fractional crystallization from hydrous basalt. Almeev et al. (2013) used a basaltic andesite with variable $\mathrm{H}_{2} \mathrm{O}-\mathrm{CO}_{2}\left(\mathrm{xH}_{2} \mathrm{O}\right.$ from 0.0 to 1.0$)$ ratios, which was generally fluid saturated. Blatter et al. (2013) investigated a Mg-basalt similar to the initial starting material (RC156c) used in our experiments, but with higher $\mathrm{TiO}_{2}$, $\mathrm{FeO}_{\text {tot }}$ and $\mathrm{Na}_{2} \mathrm{O}$ concentrations and lower $\mathrm{Al}_{2} \mathrm{O}_{3}$ and $\mathrm{MgO}$ contents and a lower $\mathrm{H}_{2} \mathrm{O}$ content of $2.1 \mathrm{wt} \%$. The

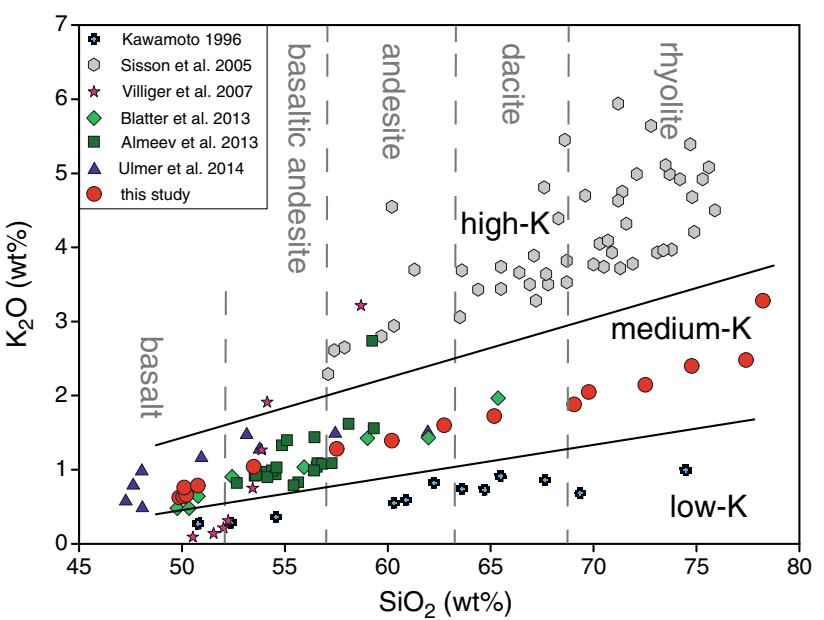

Fig. $10 \mathrm{~K}_{2} \mathrm{O}-\mathrm{SiO}_{2}(\mathrm{wt} \%)$ diagram to discriminate low-, mediumand high-K calc-alkaline series. Diagram modified after Gill (1981) by extension to higher $\mathrm{SiO}_{2}$ concentrations. Compositional boundaries of rock names used in this study for liquid compositions are indicated by gray labels and dashed lines. For data sources and experimental conditions, see Fig. 9

difference in starting composition seems not crucial with respect to the calc-alkaline trend as long as they contain $\mathrm{H}_{2} \mathrm{O}$. In Fig. 10, the $\mathrm{K}_{2} \mathrm{O}-\mathrm{SiO}_{2}$ diagram after Gill (1981) used to subdivide the calc-alkaline series further into low-, medium- and high- $\mathrm{K}$ series, the various experimental studies plot at rather different locations in this diagram, identifying the series of Kawamoto (1996) as low K, Sisson et al. (2005) as high K and this study, Almeev et al. (2013) and Blatter et al. (2013) as medium K. The different evolutionary trends are clearly related to the respective character of the starting material employed in the different studies, emphasizing the importance of the choice of the starting material as well as evidently putting some limits on the application of the experimental data to natural systems.

Figure 11 compares the liquid compositions obtained by the various studies. It should, however, be noted that all previous studies on hydrous systems at comparable pressures were crystallization experiments on fixed bulk compositions, i.e., equilibrium crystallization experiments and, thus, are not strictly comparable with the present experimental data set that additionally covers a much wider temperature and/or composition interval from a near-primary, hydrous olivine-tholeiite to high-silica rhyolite along a single liquid line of descent (LLD). For comparison, the studies of Kawamoto (1996), Sisson et al. (2005), Villiger et al. (2007), Almeev et al. (2013) and Blatter et al. (2013) were selected to highlight compositional differences of (1) tholeiitic to calc-alkaline series and (2) the importance of $\mathrm{H}_{2} \mathrm{O}$ and $\mathrm{fO}_{2}$. Additionally, we utilize data from a similar fractional crystallization study conducted at $1.0 \mathrm{GPa}$ starting from a hydrous picrobasalt (2.6 wt $\% \mathrm{H}_{2} \mathrm{O}, 47 \mathrm{wt} \% \mathrm{SiO}_{2}, 17 \mathrm{wt} \% \mathrm{MgO}$ ) originating 
from the same dike suite from the Tertiary Adamello batholith (Ulmer et al. 2014) to evaluate the pressure effect on the liquid line of descent. The liquidus temperature of the anhydrous tholeiitic system (Villiger et al. 2007) is higher for comparable starting compositions, a well-known effect and clearly related to the presence of $\mathrm{H}_{2} \mathrm{O}$ in the hydrous system. Major compositional differences are the silica content that only moderately increases in the anhydrous tholeiitic series compared to the calc-alkaline series. The rather abrupt increase in $\mathrm{SiO}_{2}$ concentration coincides with the onset of spinel (hercynite and/or Ti-magnetite) and An-rich plagioclase crystallization (this study). The $\mathrm{SiO}_{2}$ enrichment is then progressively continued with the co-precipitation of titanomagnetite, plagioclase and amphibole. Similar behavior is reported by the data presented by Kawamoto (1996), Almeev et al. (2013) and Blatter et al. (2013) and is intimately linked in the latter cases to extensive amphibole crystallization. The 1.0-GPa fractional crystallization experiments (Ulmer et al. 2014) reveal a similar behavior as the 0.7-GPa fractional data with abruptly increasing silica contents at $1,140{ }^{\circ} \mathrm{C}$ linked to the crystallization of abundant $(5 \mathrm{wt} \%$ ) hercynitic spinel over a small temperature interval. Considering all data sets together, the silica increase typical for calc-alkaline differentiation is not caused by a single phase occurring on the liquidus, but depending on bulk composition, $\mathrm{fO}_{2}$ and $\mathrm{fH}_{2} \mathrm{O}$ and pressure conditions, it is caused either by the onset of significant $\mathrm{Fe}-\mathrm{Ti}-\mathrm{Al}$ oxide crystallization with or without An-rich plagioclase or amphibole. Common to all these scenarios is the suppression of extensive plagioclase crystallization occurring in anhydrous systems and a shift of the plagioclase compositions for a given $\mathrm{Ca} / \mathrm{Na}$ ratio of the system to higher An-contents as pointed out and quantified by Sisson and Grove (1993a). Alumina (Fig. 11b) reaches considerably higher concentrations in hydrous experiments due to the suppression of plagioclase saturation toward lower temperature. This effect of $\mathrm{H}_{2} \mathrm{O}$ attributed to its depolymerizing effect on the liquid structure and thus suppression of highly polymerized phases at the expense of less polymerized phases (olivine and pyroxene) is well known and has been addressed by a number of studies (e.g., Beard and Lofgren 1991; Gaetani et al. 1993; Kawamoto 1996). The various studies conducted in hydrous systems all show significant increase in $\mathrm{Al}_{2} \mathrm{O}_{3}$ reaching 18-20 wt\%, the present one and the comparable study at $1.0 \mathrm{GPa}$ reaching the highest concentrations despite the fact that the starting materials contain the lowest $\mathrm{Al}_{2} \mathrm{O}_{3}$ concentrations (Ulmer et al. 2014). In all studies considered here, clinopyroxene occurs on the liquidus shortly after olivine or is actually the liquidus phase (Kawamoto 1996; Sisson et al. 2005; Almeev et al. 2013) as clearly evident from the $\mathrm{CaO}$ evolution (Fig. 11d) that monotonically decreases with the exception of Blatter et al. (2013) and Ulmer et al. (2014) that show a small interval of $\mathrm{CaO}$ increase where olivine ( $\pm \mathrm{Cr}$-rich spinel) is the only liquidus phase. The behavior of $\mathrm{TiO}_{2}$ (Fig. 11c) is controlled by Fe-Ti oxides (and at lower temperature also amphibole) and is dependent on initial $\mathrm{TiO}_{2}$ concentration, $\mathrm{H}_{2} \mathrm{O}$ content and $\mathrm{fO}_{2}$. Villiger et al. (2007) saturate ilmenite ( $\mathrm{fO}_{2}$ buffered by $\mathrm{C}-\mathrm{CO}_{2}$, below FMQ at $0.7 \mathrm{GPa}$, Ulmer and Luth 1991), which decreases not only the titanium but also the iron concentration in the liquid significantly. In more oxidized systems (FMQ to $\mathrm{Re}-\mathrm{ReO}_{2}$ ), the prevalent Ti-bearing phase is magnetiteulvöspinel solid solution. Amphibole incorporates also a significant amount of titanium, and its modal abundance is higher than that of $\mathrm{Fe}-\mathrm{Ti}$ oxides. The $\mathrm{FeO}_{\text {tot }}$ concentration in hydrous systems is monotonically decreasing unlike in the tholeiitic system (Villiger et al. 2007) due to increased $\mathrm{H}_{2} \mathrm{O}$ activity, which depresses the stability of silicate minerals relative to Fe-Ti oxides (Beard and Lofgren 1991; Sisson and Grove 1993a). The overall trends for most oxide concentrations for hydrous experiments around $0.7 \mathrm{GPa}$ are consistent with each other; some differences (e.g., $\mathrm{K}_{2} \mathrm{O}$ and potentially also $\mathrm{P}_{2} \mathrm{O}_{5}$ ) are clearly related to differences in the starting composition preferentially affecting the most incompatible elements. The fundamental difference between the fractional crystallization experiments conducted in this study compared with equilibrium crystallization experiments performed in previous studies is that in our study, the evolution of the intermediate and acidic differentiates is not "preconditioned" by the choice of the starting material except for the most incompatible elements. Another important difference is that peritectic reactions (see below) in particular olivine + liquid $=$ opx and the amphibole-forming reactions involving pyroxenes \pm plagioclase $\pm \mathrm{Fe}-\mathrm{Ti}$ oxide are suppressed in the present study, but in equilibrium experiments often limit the compositional range of differentiates that can be attained for a given starting composition.

A comparison of the results of the experimental study with thermodynamic calculations using MELTS (Ghiorso and Sack 1995; Asimow and Ghiorso 1998) is provided as Electronic Supplementary Material (ESM 3) revealing that fractional crystallization calculations employing the Rhyolite-MELTS code (Gualda et al. 2012) fails to predict some of the typical characteristics such as strong silica enrichment and results alumina contents far in excess of the observed ones along the liquid line of descent. This is not surprising as it is clearly stated on the MELTS homepage (http://melts.ofm-research.org/ December 2013) that "phase equilibria involving hornblende and biotite are not modeled well by the MELTS package and consequently simulating the evolution of intermediate to silica-rich calcalkaline systems is not recommended." 

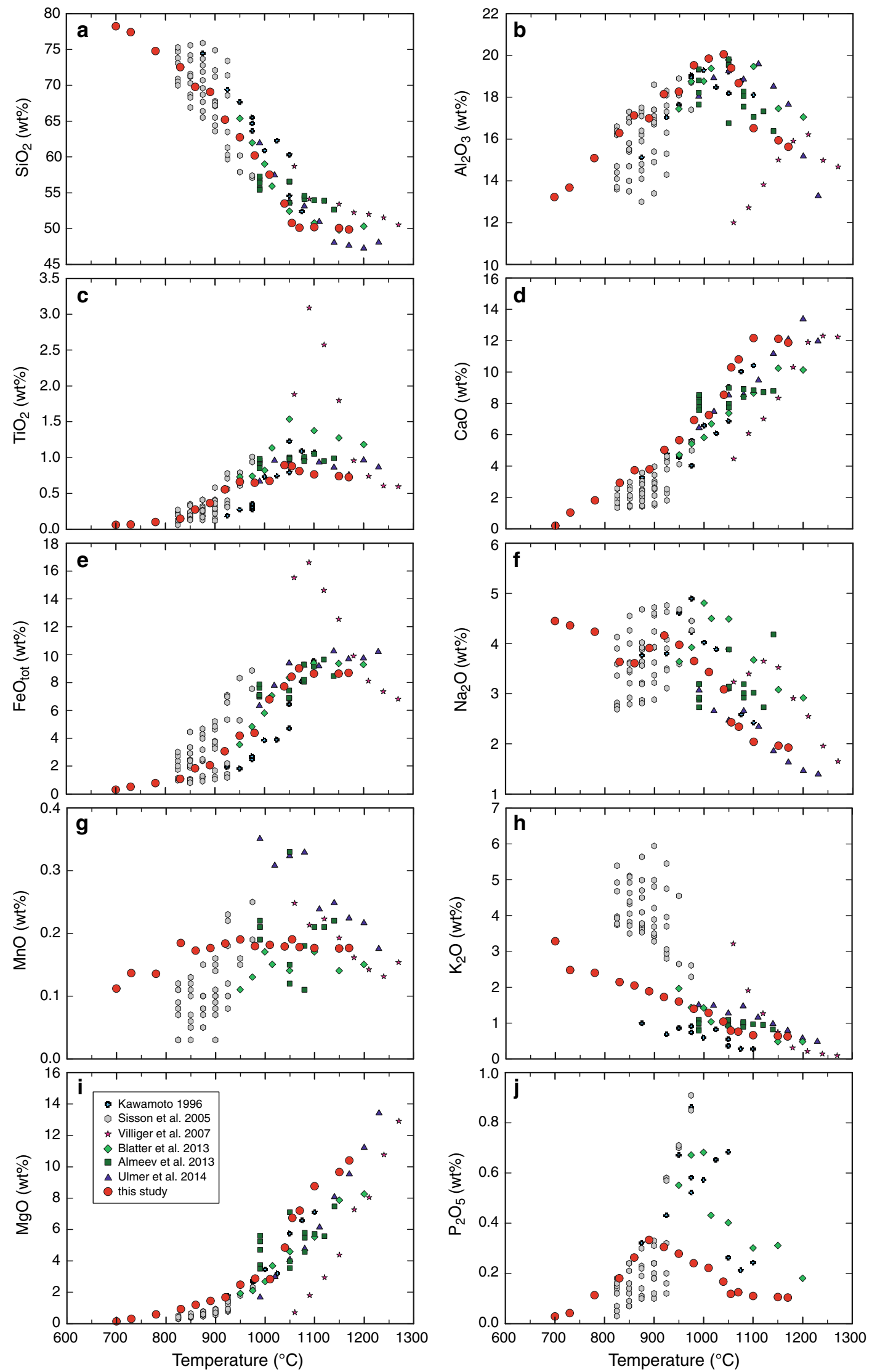
4Fig. 11 Comparison of liquid oxide concentrations (wt \%) of this study with other experimental studies at similar conditions as a function of experimental temperature. For data sources and conditions, see Fig. 9

Liquid lines of descent and phase relations in ternary projections

Figure 12a provides the compositional variations of the liquids and selected mineral phases of the $0.7 \mathrm{GPa}$ experiments in a pseudoternary $\mathrm{Ol}-\mathrm{Cpx}-\mathrm{Qtz}$ diagram projected from plagioclase, orthoclase and $\mathrm{Fe}-\mathrm{Ti}-\mathrm{Cr}$ oxides after Grove et al. (1992). Temperatures (Fig. 12a) and coexisting solid phase assemblages are specified along the liquid lines of descent for each melt projection point. The highest temperature experiments of this study are dominated by crystallization of olivine and subsequent clinopyroxene. The liquid line of descent (LLD) moves toward the Cpx corner as long as olivine is the dominating phase, but turns sharply when the proportions of clinopyroxene are becoming dominant moving away from the cpx-olivine sideline toward the Ol-Qtz sideline. The LLD crosses the Ol-Qtz sideline at about $1,010{ }^{\circ} \mathrm{C}$ becoming corundumnormative (peraluminous, negative $\mathrm{Cpx}$ coordinate) coinciding with the onset of amphibole fractionation and concomitantly with plagioclase (projecting phase) and small amounts of opx and titanomagnetite. At this point, the LLD bends toward the Qtz corner principally driven by

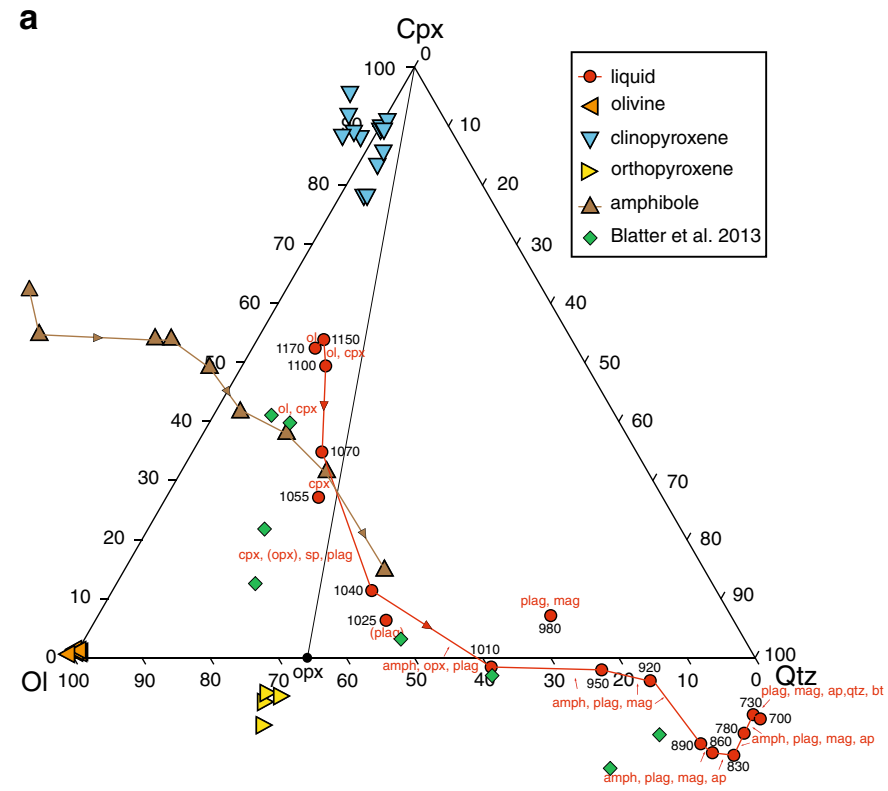

Fig. 12 Normative molecular, pseudoternary olivine (Ol)-clinopyroxene (Cpx)-quartz (Qtz) projections using the projection scheme of Grove et al. (1992) projected from plagioclase, orthoclase and Fe-TiCr oxide for a liquid (glass), selected solid phases of this study and liquid compositions from Blatter et al. (2013); b comparison of liquid amphibole fractionation. The amphibole compositions are provided for reference; they change their compositions from nepheline-normative (negative Qtz coordinate) to Qtz saturated (inside the Cpx-Ol-opx subtriangle) to finally Qtz oversaturated (Cpx-Qtz-opx) with decreasing temperature. From 1,010 to $730{ }^{\circ} \mathrm{C}$ the LLD follows and outlines the amphibole stability field. The final bend at low temperatures toward the Qtz corner is most likely a computational artifact caused by the large amount of Qtz in the calculated normative mineral modes with small amounts of negative $\mathrm{Cpx}$ and $\mathrm{Ol}$ (with large amounts of plag not considered as it is a projection phase); the liquids, however, strictly remain peraluminous.

Figure $12 \mathrm{~b}$ compares the LLD of the present study with that of Ulmer et al. (2014) at 1.0 GPa who started the fractionation experiments with a picrobasaltic composition containing a considerably higher normative olivine content, and therefore, their liquid line of descent starts closer to the Ol-apex compared to the olivine-tholeiitic starting composition employed in this study. The two LLDs at 0.7 and 1.0 GPa converge on their way toward the $\mathrm{Ol}-\mathrm{Qtz}$ sideline. This convergence is enhanced because in the $1.0 \mathrm{GPa}$ experiments olivine and cpx crystallize more abundantly (generating nearly $50 \%$ dunitic, wehrlitic and (clino)pyroxenitic cumulates) deflecting the LLD more effectively toward the Qtz corner. The crossing point (marked with a black dot) of both LLDs coincides with the onset of amphibole crystallization: at $0.7 \mathrm{GPa}$, amphibole and

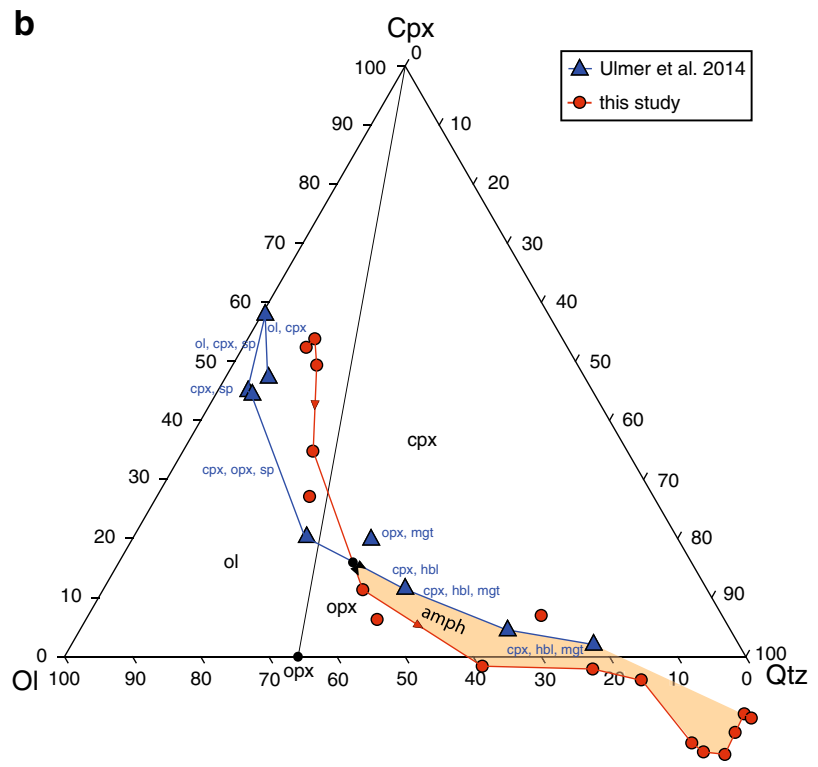

compositions from this study with liquids obtained in the fractional crystallization experiments of Ulmer et al. (2014) conducted at 1.0 $\mathrm{GPa}$. Labels in a denote run temperatures and in b coexisting solid assemblages 
orthopyroxene crystallize concomitantly with plagioclase and Ti-magnetite, whereas at $1.0 \mathrm{GPa}$, amphibole coexists with clinopyroxene and magnetite. The crossover of the two LLDs at 0.7 and $1.0 \mathrm{GPa}$ is evidently related to (1) the coexisting parageneses: amphibole + orthopyroxene + plagioclase (the projection phase of Cawthorn and O'Hara 1976) at $0.7 \mathrm{GPa}$ versus amphibole + clinopyroxene at $1.0 \mathrm{GPa}$; and (2) the likely existence of a diverging peritectic point encompassing the amphibole stability field with the orthopyroxene-amphibole (+plagioclase +Ti-magnetite) forming the lower branch and clinopyroxene-amphibole (+Ti-magnetite) forming the upper branch (Fig. 12b). A similar reaction scheme, termed "distributary reaction," was previously proposed for the appearance of amphibole at $0.2 \mathrm{GPa}$ involving olivine and clinopyroxene instead of clinopyroxene and orthopyroxene (Sisson and Grove $1993 a, b)$. The exact path at amphibole saturation potentially depends on several parameters: (i) pressure (and $\mathrm{Na}_{2} \mathrm{O}$ and $\mathrm{H}_{2} \mathrm{O}$ content of the initial liquid) suppressing plagioclase stabilization at $1.0 \mathrm{GPa}$ potentially leading to more calcic liquids saturating clinopyroxene instead of orthopyroxene, (ii) silica activity that is probably higher in the $0.7 \mathrm{GPa}$ experiment due to less orthopyroxene being extracted in the steps prior to amphibole saturation, favoring orthopyroxene crystallization at lower temperatures and (iii) generally more extensive crystallization at 1.0 GPa (lower melt fraction left) before the onset of amphibole crystallization than at $0.7 \mathrm{GPa}$. Theoretically, peritectic reactions should only be recorded by a change in the crystallizing mineral assemblage in perfect fractional experiments. However, we approach fractional crystallization in a stepwise approach, always oversaturating the liquid coexisting with solids at a $30{ }^{\circ} \mathrm{C}$ lower temperature. Therefore, peritectic reactions will definitely influence the crystallization paths (LLD) during crystallization-driven differentiation.

The generation of peraluminous differentiates

The contrasting phase assemblages observed at 0.7 and $1.0 \mathrm{GPa}$ at the onset of amphibole crystallization leads to the evolution of the liquids at $0.7 \mathrm{GPa}$ into the corundumnormative peraluminous field (negative cpx-component) at a $\mathrm{SiO}_{2}$ content of $62 \mathrm{wt} \%$. The LLD at $1.0 \mathrm{GPa}$ ends at $990{ }^{\circ} \mathrm{C}$ with a $\mathrm{SiO}_{2}$ content of $62 \mathrm{wt} \%$ (volatile-free basis) just inside the metaluminous field, its continuation most likely will also cross the metaluminous-peraluminous join assuming amphibole crystallization is continued. The LLD of this study has been extended to $700{ }^{\circ} \mathrm{C}$ to explore the compositions of differentiated dacitic to rhyolitic liquids that are all peraluminous (Fig. 13) and, except for the last fractionation step at $700{ }^{\circ} \mathrm{C}$, coexist with amphibole, relatively $\mathrm{Ca}$-rich plagioclase and titanomagnetite. This is the

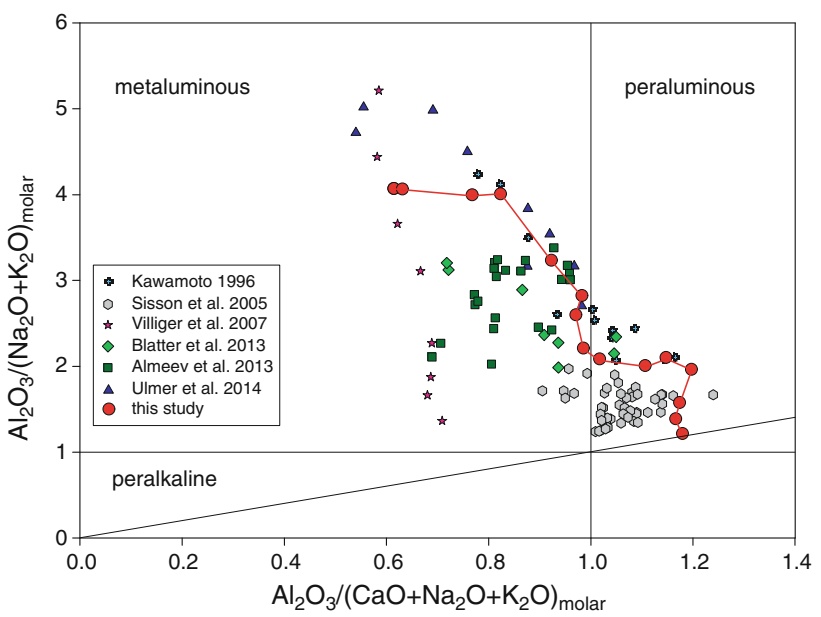

Fig. 13 Alumina saturation (ASI) versus peralkalinity (PI) index diagram modified after Maniar and Piccoli (1989) discriminating metaluminous, peraluminous and peralkaline liquids. For data sources, see Fig. 9

most typical gabbroic assemblage found in intermediate to deep-crustal hydrous, calc-alkaline plutonic rocks (e.g., Davidson et al. 2007; Larocque and Canil 2010; Dessimoz et al. 2012) and testifies that differentiation from intermediate (andesitic) to acidic calc-alkaline magmas involves extensive crystallization of amphibole-gabbros.

The aluminum is concentrated in the hydrous liquid as a consequence of the enhanced clinopyroxene and amphibole crystallization at elevated pressure $(0.7 \mathrm{GPa})$ and $\mathrm{H}_{2} \mathrm{O}$ contents relative to orthopyroxene and plagioclase under lower pressure and/or lower $\mathrm{H}_{2} \mathrm{O}$ contents. Liquid compositions reach peraluminous compositions (Fig. 13) at $\mathrm{SiO}_{2}$ contents of $65.2 \mathrm{wt} \%$ (62.3 wt\% (Kawamoto 1996); $64.4 \mathrm{wt} \%$ (Sisson et al. 2005) and $60.5 \mathrm{wt} \%$ (Blatter et al. 2013)). Cawthorn et al. (1976) already stated that the exact value of the $\mathrm{SiO}_{2}$ content at which the liquids become corundum-normative varies considerably. Sisson et al. (2005) reported only metaluminous liquid compositions for the most reducing experiments. For comparison, the anhydrous tholeiitic series of Villiger et al. (2007) is strictly metaluminous, and there is no indication that even more differentiated liquids would approach the metaluminous-peraluminous boundary; the principle difference being the more prominent role of orthopyroxene in the fractionating assemblage. As proposed by several studies, experimentally and field based (e.g., Cawthorn et al. 1976; Müntener et al. 2001; Davidson et al. 2007), the formation of corundum-normative intermediate to acidic (dacite to rhyolite) magmas does not a priori require contamination by or assimilation of partial melts derived from pelitic crustal lithologies as anticipated in numerous studies (Wall et al. 1987; Clemens 1989; Clemens et al. 2011), but can be achieved by fractional crystallization of hydrous basaltic 
parental magmas in mid to lower crustal $(>0.6 \mathrm{GPa}$ ) magma reservoirs. At least in the case of the Adamello batholith, corundum-normative tonalites and granodiorites systematically show REE patterns that are indicative for extensive amphibole and very late plagioclase fractionation (e.g., Ulmer 2007). Interestingly, these are the least crustally contaminated rocks in the entire batholiths with the lowest $\varepsilon \mathrm{Sr}$ and highest $\varepsilon \mathrm{Nd}$ (Kagami et al. 1991; Hürlimann et al. 2014) and $\varepsilon H f$ (Broderick 2013) values, approaching pristine mantle values, thus supporting the derivation of corundum-normative intermediate to acidic magmas by crystallization dominated processes at mid to lower crustal conditions instead of invoking large amounts of crustal contamination.

Melt fraction as a function of temperature and some rheologic consequences

Figure 14 displays a diagram illustrating melt fractions relative to the initial mass (ol-tholeiite RC156c) and the solid fraction extracted in each temperature step relative to the initial magma mass as a function of temperature. The observed relationship is distinctly nonlinear: A first interval between the liquidus around $1,170{ }^{\circ} \mathrm{C}$ and $1,100{ }^{\circ} \mathrm{C}$ (I) is characterized by minor $(<10 \%)$ olivine and clinopyroxene extraction, between 1,070 and $1,010{ }^{\circ} \mathrm{C} 50 \%$ of the original mass crystallizes to clinopyroxene with minor plagioclase and hercynitic spinel followed by amphibole plus plagioclase plus minor opx. The peritectic reaction at $1,020{ }^{\circ} \mathrm{C}$ does not result in a significant increase in the solid fraction, because fractional crystallization suppresses the peritectic reaction that is just reflected by a change in the crystalizing assemblage from clinopyroxene-dominated to amphibole + plagioclase-dominated solid assemblages. This massive crystallization interval (II) prior to and at the onset of amphibole crystallization is also responsible for effectively driving the liquid composition from basalt to andesite. The following large temperature interval (III) of $280{ }^{\circ} \mathrm{C}$ toward the granite eutectic below $700{ }^{\circ} \mathrm{C}$ (not determined in this study, but located by Stern et al. (1975) around $650{ }^{\circ} \mathrm{C}$ for $\mathrm{H}_{2} \mathrm{O}$-saturated conditions) is characterized by much reduced crystallization of a single paragenesis composed of amphibole-plagioclase-magnetite with accessory apatite joining around $860{ }^{\circ} \mathrm{C}$. The solid fraction extracted over this entire $280{ }^{\circ} \mathrm{C}$ interval only amounts to about $20 \%$ (relative to the starting olivine-tholeiitic liquid), leaving about $20 \%$ of the original mass as highsilica rhyolite that solidifies at the granite-eutectic minimum over a small temperature interval $\left(650-700{ }^{\circ} \mathrm{C}\right.$; Stern et al. 1975). To emphasize the importance of fractional versus equilibrium crystallization, Fig. 14 shows in addition the results of equilibrium crystallization experiments at an identical pressure $(0.7 \mathrm{GPa})$ on similar near-primary, arc-related, hydrous basalts from Blatter et al. (2013) and Melekhova et al. (2013) for two initial $\mathrm{H}_{2} \mathrm{O}$ contents (2.3 and $4.5 \mathrm{wt} \%$ ) that bracket the $3.0 \mathrm{wt} \%$ of the initial, basaltic starting material of this study. The evolutionary trends of the equilibrium crystallization experiments are significantly different from the trends obtained in this study: The melt fraction and the evolution to more differentiated (silica rich) compositions span a much smaller temperature interval: Melekova et al. (2013) with $2.3 \mathrm{wt} \%$ $\mathrm{H}_{2} \mathrm{O}$ already obtained at $1,000{ }^{\circ} \mathrm{C}$ a granitic liquid (75.1 $\mathrm{wt} \% \mathrm{SiO}_{2}$ ) at a melt fraction less than $10 \%$, whereas in the present study the liquid at $1,010{ }^{\circ} \mathrm{C}$ is andesitic $(56.6 \mathrm{wt} \%$ $\mathrm{SiO}_{2}$ ) at a melt fraction of $45 \%$. With an initial $\mathrm{H}_{2} \mathrm{O}$ content of $4.5 \mathrm{wt} \%$, a melt fraction of $35 \mathrm{wt} \%$ and an andesitic liquid (56.9 wt\%) exists in the equilibrium crystallization experiments, whereas in the fractional case, at the same temperature, $75 \%$ liquid of basaltic composition (50.8 wt\% silica) is present. Likewise, Blatter et al. (2013) obtain a dacitic liquid $\left(62 \mathrm{wt} \% \mathrm{SiO}_{2}\right)$ representing $17 \mathrm{wt} \%$ melt fraction at $975{ }^{\circ} \mathrm{C}$. It is obvious that the suppression of peritectic reactions results in both much smoother melt fraction-temperature as well as melt evolution (differentiation)-temperature relationships. There is still a region (II, Fig. 14) that is dominated by rapid decrease in melt fraction and enhanced differentiation, but both effects are much weaker for fractional than for the equilibrium crystallization. As pointed out by Melekhova et al. (2013), the strongly nonlinear crystallization behavior with respect to temperature dictates the chemical evolution of magmas differentiating in mid-crustal magma reservoirs and it most likely also controls the dynamics of magma reservoirs and the extraction of liquids from solid residues: At the onset of crystallization, minor olivine and clinopyroxene crystallization generates phenocryst-poor magmas that form dilute suspensions; magma viscosity remains low, close to the liquid viscosity (e.g., Caricchi et al. 2007; Costa et al. 2009; Pistone et al. 2012). Separation of crystals and liquid is difficult in particular when magmas are convecting or rapidly ascending. The significant increase in crystallinity over a small temperature interval (II, Fig. 14) brings the magma close to or within the rigid percolation threshold (RPT; Vigneresse et al. 1996) corresponding to the formation of a randomly loose packed crystal framework and coincides with the transition from a dilute to a concentrated suspension (Pistone et al. 2013). Such rheological conditions enable the partitioning of strain to form melt-enriched (dilatant) regions and crystal-rich (compressive) regions ultimately generating pathways to efficiently extract liquids from solids in a deforming crystal mush. Thus, we propose that the rapid increase in the crystal content in the crystallizing magma over a short temperature interval generates ideal rheological conditions for melt extraction just after the switch from pyroxene to amphibole-dominated solid 


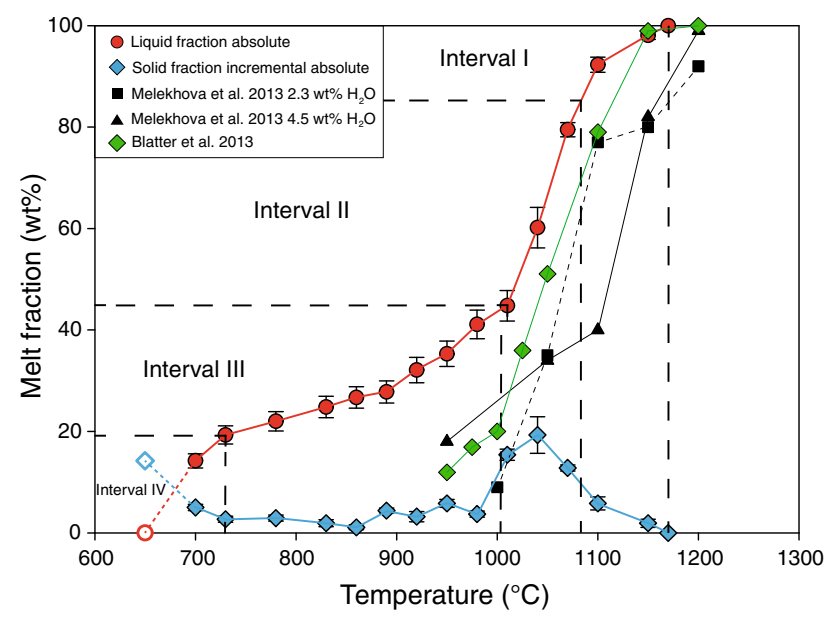

Fig. 14 Melt fraction relative to initial mass of melt and solid fraction relative to initial mass of melt (wt\%) as a function of temperature. For comparison and discussion, the melt fractions obtained by Melekhova et al. (2013) for equilibrium crystallization of a primitive Mg-rich basalt at $0.7 \mathrm{GPa}$ for 2.3 and $4.5 \mathrm{wt} \% \mathrm{H}_{2} \mathrm{O}$ and by Blatter et al. (2013) at 0.7 GPa for a basalt with $2.0 \mathrm{wt} \% \mathrm{H}_{2} \mathrm{O}$ are indicated

assemblages. The extracted liquids would be a typical andesite, the most common bulk rock composition observed in plutonic and volcanic rocks in convergent plate margin magmatism (e.g., Gill 1981). Therefore, the dominance of andesitic compositions in supra-subduction igneous provinces is probably just the consequence of the topology of the underlying phase diagram and the thermodynamically controlled phase occurrence and proportions. Under mid-crustal conditions investigated in this study, basaltic liquids differentiate over a small temperature interval $\left(60-80{ }^{\circ} \mathrm{C}\right)$ to andesite and produce an amount of solid phases that changes the rheology of the suspension to enable extraction of the liquid from the crystal mush. The buoyant andesitic magmas extracted from the crystal mush most likely ascend further through the crust and lead to the formation of plutonic complexes in shallower crustal levels. Provided governing phase assemblages and modal proportions do not change significantly at somewhat lower pressure, the present experiments imply that this andesitic magma will not reach the RPT until approaching the granite minimum at temperatures around $710{ }^{\circ} \mathrm{C}$ when a total amount of $50 \%$ of the extracted andesite magma will have crystallized to amphibole + plagioclase + magnetite (reducing the melt fraction from 40 to $20 \%$ relative to the starting basalt). Over this large temperature interval $\left(280{ }^{\circ} \mathrm{C}\right)$, the magma potentially behaves as a dilute suspension, which not only allows rapid ascent in dikes, but also further enables the buildup of highly dynamic, convecting magma reservoirs within the crust. Only when the granite minimum is approached, will the magma reach the RPT where the extraction of a high-silica-rich rhyolitic liquid could occur (e.g., Bachmann and Bergantz 2004).
The scenario depicted in the previous paragraph cannot be strictly derived from the experimental data set presented in this study for the following reasons: (1) the processes envisaged propose polybaric evolution from a lower midcrustal magma reservoir generating the andesitic liquids that is emplaced at shallower level forming intermediate to acidic plutonic complexes or even erupt at the surface of the Earth. This would require polybaric fractional crystallization experiments and/or a coherent data set to predict polybaric behavior; and (2) the scenario implicitly does not represent (near) perfect fractional crystallization but a combination of fractional and equilibrium crystallization; such a concept is also favored by Melekhova et al. (2013). Liquids are only extracted when the rheologic RPT is reached; thus, magmas are allowed to equilibrate (at least to a certain extent) with the solid residue. However, the amphibole + plagioclase + magnetite crystallization interval (III) is characterized by cotectic crystallization of the observed phases, and thus, we do not anticipate significant difference between fractional and equilibrium crystallization regarding melt compositions and melt fractions potentially allowing to apply the results of this study directly to natural systems. Nevertheless, equilibrium crystallization experiments that partly exist (Kawamoto 1996; Sisson et al. 2005; Almeev et al. 2013; Blatter et al. 2013; Melekhova et al. 2013) should be combined with this study to better constrain phase assemblages, liquid compositions and melt fractions as a function of temperature and pressure with the ultimate goal to provide a consistent model of convergent margin magmatism that not only takes into account thermodynamic (chemical and energetic) constraints but also physical (rheologic, density) considerations to understand the crustal evolution of such magmatic systems.

\section{Conclusion}

Near-perfect fractional crystallization experiment at 0.7 GPa from the hydrous basalt liquidus close to the $\mathrm{H}_{2} \mathrm{O}$ saturated granite solidus results that the presence of moderate amounts of $\mathrm{H}_{2} \mathrm{O}(3 \mathrm{wt} \%)$ in the parental magma is sufficient to drive the liquid line of descent from tholeiitic (anhydrous) to calc-alkaline (hydrous) by suppressing crystallization of plagioclase and enhancing the crystallization of clinopyroxene and magnetite thereby inhibiting iron enrichment characterizing the tholeiitic evolutionary trend. Silica enrichment, the other prominent characteristic of calc-alkaline magmas, is achieved by crystallization of anorthitic plagioclase, amphibole and $\mathrm{Fe}-\mathrm{Ti}$ oxide. Amphibole stability in intermediate calc-alkaline magmas is governed by a diverging peritectic encompassing the amphibole stability field. Depending on pressure and 
probably also $\mathrm{H}_{2} \mathrm{O}$ and $\mathrm{Na}_{2} \mathrm{O}$ contents of the system, the amphibole stability field is delimited by reactions (1) involving clinopyroxene + liquid \pm plagioclase and (2) olivine or orthopyroxene + liquid \pm plagioclase. The amphibole stability field is known to be rather small in compositional space (Helz 1976; Allen and Boettcher 1983; Huang and Wyllie 1986; Hilyard et al. 2000) and, therefore, sensitive to small changes in the solid phase assemblages crystallized before reaching the amphibole field. In the present case, the system crystallized along the orthopyroxene-amphibole-plagioclase reaction boundary (Fig. 12) to peraluminous derivative liquids. In order to reach the amphibole stability field, extensive fractionation of clinopyroxene accompanied by minor plagioclase and spinel extraction, solidifying $50 \%$ of the original melt mass within a short temperature interval must take place; this might also occur at lower levels within the crust or even within the uppermost mantle. Amphibole systematically varies in composition with decreasing temperature from nepheline- to quartz-normative and significantly contributes to drive derivative liquids to peraluminous compositions. A typical gabbroic mineral assemblage composed of amphibole, plagioclase and magnetite crystallizes over a $280{ }^{\circ} \mathrm{C}$ temperature interval while coexisting liquids differentiate from andesite to high-silica rhyolite. The formation of high-silica rhyolite from andesite at midcrustal levels requires about $50 \%$ extraction of gabbroic cumulates leaving about $20 \%$ rhyolite relative to the mass of the initial basaltic mantle-derived magma.

Corundum-normative (Chayes 1969) volcanics and peraluminous granitoid rocks (Williams et al. 1955) are a common product in supra-subduction zone igneous systems. This experimental study demonstrates that such compositions can be produced from primitive mantlederived basaltic melts by fractional crystallization at 0.7 GPa corresponding to mid-crustal levels.

The strongly nonlinear melt fraction-temperature relationships along the liquid line of descent potentially results in two temperature-compositional windows where melt extraction is most effective; a first one just above $1,000{ }^{\circ} \mathrm{C}$ where an andesitic liquid coexists with an ultramafic (clinopyroxenitic) to mafic (gabbro to amph-gabbro) crystal mush and a second one below $710{ }^{\circ} \mathrm{C}$ where a highsilica rhyolite coexists with an amphibole-bearing diorite/ tonalite. Above $1,070{ }^{\circ} \mathrm{C}$ and between 1,000 and $710^{\circ} \mathrm{C}$, crystal poor to moderately crystalline basalts, basaltic andesites and andesites form highly mobile melts potentially ascending through the crust reaching higher-level reservoirs.

Acknowledgments The work is part of the ProDoc program "4-D Adamello" and was supported by the Swiss National Science
Foundation (grants PDFMP2-123097/1 and PDAMP2-123074). We would like to acknowledge Eric Reusser for his help using EPMA and Micro-Raman spectroscopy. Thoughtful comments by Tom Sisson on an earlier version of this manuscript are gratefully acknowledged. Constructive comments by two anonymous reviewers helped improve this manuscript.

\section{References}

Allen JC, Boettcher AL (1983) The stability of amphibole in andesite and basalt at high pressures. Am Mineral 68(3-4):307-314

Almeev RR, Holtz F, Ariskin AA, Kimura JI (2013) Storage conditions of Bezymianny Volcano parental magmas: results of phase equilibria experiments at 100 and $700 \mathrm{MPa}$. Contrib Mineral Petrol 166(5):1389-1414. doi:10.1007/s00410-0130934-X

Alonso-Perez R (2006) The role of garnet in the evolution of hydrous, calc-alkaline magmas: An experimental study at 0.8-1.5 GPa. $\mathrm{PhD}$ thesis ETH No 16999

Asimow PD, Ghiorso MS (1998) Algorithmic modifications extending MELTS to calculate subsolidus phase relations. Am Mineral 83(9-10):1127-1132

Bachmann O, Bergantz GW (2004) On the origin of crystal-poor rhyolites: extracted from batholithic crystal mushes. J Petrol 45(8):1565-1582. doi:10.1093/petrology/egh019

Beard JS, Lofgren GE (1991) Dehydration melting and watersaturated melting of basaltic and andesitic greenstones and amphibolites at 1, 3 and $6.9 \mathrm{~kb}$. J Petrol 32(2):365-401

Blatter DL, Sisson TW, Hankins WB (2013) Crystallization of oxidized, moderately hydrous arc basalt at mid- to lower-crustal pressures: implications for andesite genesis. Contrib Mineral Petrol 166(3):861-886. doi:10.1007/s00410-013-0920-3

Bohlen SR, Essene EJ, Boettcher AL (1980) Reinvestigation and application of olivine-quartz-orthopyroxene barometry. Earth Planet Sci Lett 47(1):1-10. doi:10.1016/0012-821x(80)90098-9

Bose K, Ganguly J (1995) Quartz-coesite transition revisited: reversed experimental-determination at 500-1200-degrees-C and retrieved thermochemical properties. Am Mineral 80(3-4): 231-238

Bowen N (1928) The evolution of the igneous rocks. Princeton University Press, Princeton

Broderick C (2013) Timesclaes and petrologic processes during incremental pluton assembly: a case study from the Val Fredda Complex, Adamello Batholith, N. Italy. Phd thesis University of Geneva

Brown M, Solar GS (1998) Granite ascent and emplacement during contractional deformation in convergent orogens. J Struct Geol 20(9-10):1365-1393. doi:10.1016/s0191-8141(98)00074-1

Caricchi L, Burlini L, Ulmer P, Gerya T, Vassalli M, Papale P (2007) Non-Newtonian rheology of crystal-bearing magmas and implications for magma ascent dynamics. Earth Planet Sci Lett 264(3-4):402-419. doi:10.1016/j.epsl.2007.09.032

Cawthorn RG, O'Hara MJ (1976) Amphibole fractionation in calcalkaline magma genesis. Am J Sci 276(3):309-329

Cawthorn RG, Strong DF, Brown PA (1976) Origin of corundumnormative intrusive and extrusive magmas. Nature 259(5539):102-104. doi:10.1038/259102a0

Chayes F (1969) The chemical composition of Cenozoic andesite. In: McBirney AR (ed) Proceedings of the andesite conference: state of Oregon, Dept Geol Mineral Ind Bull, vol 65. pp 1-12

Clemens JD (1989) The Importance of Residual Source Material (Restite) in Granite Petrogenesis: a Comment. J Petrol 30(5):1313-1316 
Clemens JD, Mawer CK (1992) Granitic magma transport by fracture propagation. Tectonophysics 204(3-4):339-360. doi:10.1016/ 0040-1951(92)90316-x

Clemens JD, Stevens G, Farina F (2011) The enigmatic sources of I-type granites: the peritectic connexion. Lithos 126(3-4): 174-181. doi:10.1016/j.lithos.2011.07.004

Costa A, Caricchi L, Bagdassarov N (2009) A model for the rheology of particle-bearing suspensions and partially molten rocks. Geochemistry Geophysics Geosystems 10. doi:10.1029/2008gc002138

Davidson J, Turner S, Handley H, Macpherson C, Dosseto A (2007) Amphibole "sponge" in arc crust? Geology 35(9):787-790. doi:10.1130/g23637a.1

Dessimoz M, Müntener O, Ulmer P (2012) A case for hornblende dominated fractionation of arc magmas: the Chelan Complex (Washington Cascades). Contrib Mineral Petrol 163(4):567-589. doi:10.1007/s00410-011-0685-5

Di Muro A, Villemant B, Montagnac G, Scaillet B, Reynard B (2006) Quantification of water content and speciation in natural silicic glasses (phonolite, dacite, rhyolite) by confocal microRaman spectrometry. Geochim Cosmochim Acta 70(11):2868-2884. doi:10.1016/j.gca.2006.02.016

Gaetani GA, Grove TL, Bryan WB (1993) The influence of water on the petrogenesis of subductionrelated igneous rocks. Nature 365(6444):332-334. doi:10.1038/365332a0

Ghiorso MS, Sack RO (1995) Chemical Mass Transfer in Magmatic Processes. IV. A Revised and Internally Consistent Thermodynamic Model for the Interpolation and Extrapolation of LiquidSolid Equilibria in Magmatic Systems at Elevated Temperatures and Pressures. Contrib Mineral Petrol 119(2-3):197-212. doi:10. 1007/bf00307281

Gill J (1981) Orogenic andesites and plate tectonics. Springer, New York

Goldstein JI, Newbury DE, Echlin P, Joy DC, Fiori C, Lifshin E (1992) Scanning electron microscopy and x-ray microanalysis. Plenum Press, New York

Gualda GAR, Ghiorso MS, Lemons RV, Carley TL (2012) RhyoliteMELTS: a Modified Calibration of MELTS Optimized for Silica-rich. Fluid-bearing Magmatic Systems. J Petrol 53(5):875-890. doi:10.1093/petrology/egr080

Helz RT (1976) Phase relations of basalts in their melting ranges at $\mathrm{PH}_{2} \mathrm{O}=5 \mathrm{~kb}$. Part II. Melt compositions. J Petrol 17(2): 139-193

Hernlund J, Leinenweber K, Locke D, Tyburczy JA (2006) A numerical model for steady-state temperature distributions in solid-medium high-pressure cell assemblies. Am Mineral 91(2-3):295-305. doi:10.2138/am.2006.1938

Hildreth W, Moorbath S (1988) Crustal contributions to arc magmatism in the Andes of Central Chile. Contrib Mineral Petrol 98(4):455-489. doi:10.1007/bf00372365

Hilyard M, Nielsen RL, Beard JS, Patino-Douce A, Blencoe J (2000) Experimental determination of the partitioning behavior of rare earth and high field strength elements between pargasitic amphibole and natural silicate melts. Geochim Cosmochim Acta 64(6):1103-1120. doi:10.1016/s0016-7037(99)00379-8

Huang WL, Wyllie PJ (1986) Phase relationships of gabbro-tonalitegranite-water at $15 \mathrm{kbar}$ with applications to differentiation and anatexis. Am Mineral 71(3-4):301-316

Hürlimann N, Müntener O, Ulmer P, Chiaradia M, Nandedkar R (2014) Fractionation of primitive arc-tholeiite magmas to corundum normative dacites. J Petrol submitted

Iacono-Marziano G, Morizet Y, Le Trong E, Gaillard F (2012) New experimental data and semi-empirical parameterization of $\mathrm{H}_{2} \mathrm{O}$ $\mathrm{CO}_{2}$ solubility in mafic melts. Geochim Cosmochim Acta 97:1-23. doi:10.1016/j.gca.2012.08.035

Irvine TN, Baragar WRA (1971) A guide to the chemical classification of the common volcanic rocks. Can J Earth Sci 8(5):523-548
Jagoutz O, Müntener O, Schmidt MW, Burg J-P (2011) The roles of flux- and decompression melting and their respective fractionation lines for continental crust formation: evidence from the Kohistan arc. Earth Planet Sci Lett 303(1-2):25-36. doi:10. 1016/j.epsl.2010.12.017

Kagami H, Ulmer P, Hansmann W, Dietrich V, Steiger RH (1991) $\mathrm{Nd}-\mathrm{Sr}$ isotopic and geochemical characteristics of the southern Adamello (northern Italy) intrusives: implications for crustal versus mantle origin. J Geophys Res 96(B9):14331-14346. doi: $10.1029 / 91 \mathrm{jb} 01197$

Kägi R, Müntener O, Ulmer P, Ottolini L (2005) Piston-cylinder experiments on $\mathrm{H}_{2} \mathrm{O}$ undersaturated Fe-bearing systems: an experimental setup approaching $\mathrm{f}_{\mathrm{O} 2}$ conditions of natural calcalkaline magmas. Am Mineral 90(4):708-717. doi:10.2138/am. 2005.1663

Kawamoto T (1996) Experimental constraints on differentiation and $\mathrm{H}_{2} \mathrm{O}$ abundance of calc-alkaline magmas. Earth Planet Sci Lett 144(3-4):577-589. doi:10.1016/s0012-821x(96)00182-3

Kay RW, Kay SM (1991) Creation and destruction of lower continental-crust. Geol Rundsch 80(2):259-278. doi:10.1007/ bf01829365

Korolyuk YN, Usova LV, Nigmatulina EN (2009) Accuracy in the determination of the compositions of main rockforming silicates and oxides on a JXA-8100 microanalyer. J Anal Chem 64(10):1042-1046

Kress VC, Carmichael ISE (1991) The compressibility of silicate liquids containing $\mathrm{Fe}_{2} \mathrm{O}_{3}$ and the effect of composition, temperature, oxygen fugacity and pressure on their redox states. Contrib Mineral Petrol 108(1-2):82-92. doi:10.1007/bf00307328

Kuno H (1968) Differentiation of basalt magmas. In: Hess HH, Poldervaart AA (eds) Basalts: The Poldervaart treatise on rocks of basaltic composition, vol 2. Interscience, New York, pp 623-688

Larocque J, Canil D (2010) The role of amphibole in the evolution of arc magmas and crust: the case from the Jurassic Bonanza arc section, Vancouver Island. Canada. Contrib Mineral Petrol 159(4):475-492. doi:10.1007/s00410-009-0436-z

Luth RW (1989) Natural versus experimental control of oxidation state effects on the composition and speciation of $\mathrm{C}-\mathrm{O}-\mathrm{H}$-fluids. Am Mineral 74(1-2):50-57

Maniar PD, Piccoli PM (1989) tectonic discrimination of granitoids. Geol Soc Am Bull 101:635-643

Melekhova E, Annen C, Blundy J (2013) Compositional gaps in igneous rock suites controlled by magma system heat and water content. Nat Geosci 6(5):385-390. doi:10.1038/ngeo1781

Mercier M, Di Muro A, Giordano D, Metrich N, Lesne P, Pichavant M, Scaillet B, Clocchiatti R, Montagnac G (2009) Influence of glass polymerisation and oxidation on micro-Raman water analysis in alumino-silicate glasses. Geochim Cosmochim Acta 73(1):197-217. doi:10.1016/j.gca.2008.09.030

Müntener O, Ulmer P (2006) Experimentally derived high-pressure cumulates from hydrous arc magmas and consequences for the seismic velocity structure of lower arc crust. Geophys Res Lett 33(21):L21308. doi:10.1029/2006g1027629

Müntener O, Kelemen PB, Grove TL (2001) The role of $\mathrm{H}_{2} \mathrm{O}$ during crystallization of primitive arc magmas under uppermost mantle conditions and genesis of igneous pyroxenites: an experimental study. Contrib Mineral Petrol 141(6):643-658

Newman S, Lowenstern JB (2002) VolatileCalc: a silicate melt- $\mathrm{H}_{2} \mathrm{O}$ $\mathrm{CO}_{2}$ solution model written in Visiual Basic for excel. Comput Geosci 28:597-604

Paterson SR, Fowler TK, Schmidt KL, Yoshinobu AS, Yuan ES, Miller RB (1998) Interpreting magmatic fabric patterns in plutons. Lithos 44(1-2):53-82. doi:10.1016/s0024-4937(98) 00022-x

Pistone M, Caricchi L, Ulmer P, Burlini L, Ardia P, Reusser E, Marone F, Arbaret L (2012) Deformation experiments of bubble- 
and crystal-bearing magmas: Rheological and microstructural analysis. J of Geophys Res 117. doi:10.1029/2011jb008986

Pistone M, Caricchi L, Ulmer P, Reusser E, Ardia P (2013) Rheology of volatile-bearing crystal mushes: mobilization vs. viscous death. Chem Geol 345:16-39. doi:10.1016/j.chemgeo.2013.02. 007

Rapp RP, Watson EB (1995) Dehydration melting of metabasalt at 8-32 kbar: implications for continental growth and crust-mantle recycling. J Petrol 36(4):891-931

Ratajeski K, Sisson TW (1999) Loss of iron to gold capsules in rockmelting experiments. Am Mineral 84(10):1521-1527

Sisson TW, Grove TL (1993a) Experimental investigations of the role of $\mathrm{H}_{2} \mathrm{O}$ in calc-alkaline differentiation and subduction zone magmatism. Contrib Mineral Petrol 113(2):143-166. doi:10. 1007/bf00283225

Sisson TW, Grove TL (1993b) Temperatures and $\mathrm{H}_{2} \mathrm{O}$ contents of low-MgO high-alumina basalts. Contrib Mineral Petrol 113(2):167-184. doi:10.1007/bf00283226

Sisson TW, Ratajeski K, Hankins WB, Glazner AF (2005) Voluminous granitic magmas from common basaltic sources. Contrib Mineral Petrol 148(6):635-661. doi:10.1007/s00410-004-0632-9

Spear FS, Kimball KL (1984) RECAMP_A FORTRAN IV program for estimating $\mathrm{Fe}^{3+}$ contents in amphiboles. Compu Geosci 10(2-3):317-325. doi:10.1016/0098-3004(84)90029-3

Stern CR, Huang WL, Wyllie PJ (1975) Basalt-andesite-rhyolite- $\mathrm{H}_{2} \mathrm{O}$ - Crystallization intervals with excess $\mathrm{H}_{2} \mathrm{O}$ and $\mathrm{H}_{2} \mathrm{O}$-undersaturated liquidus surfaces to 35 kilobars, with implications for magma genesis. Earth Planet Sci Lett 28(2):189-196. doi:10. 1016/0012-821x(75)90226-5

Ulmer P (1986) Basische und ultrabasische Gesteine des Adamello (Provinzen Brescia und Trento, Norditalien). PhD thesis ETH No 8105

Ulmer P (1989) The dependence of $\mathrm{Fe}^{2+}-\mathrm{Mg}$ cation-partitioning between olivine and basaltic liquid on pressure, temperature and composition An experimental study to 30 kbars. Contrib Mineral Petrol 101(3):261-273. doi:10.1007/bf00375311

Ulmer P (2001) Partial melting in the mantle wedge - the role of $\mathrm{H}(2) \mathrm{O}$ in the genesis of mantle-derived 'arc-related' magmas.
Phys Earth Planet Int 127(1-4):215-232. doi:10.1016/s00319201(01)00229-1

Ulmer P (2007) Differentiation of mantle-derived calc-alkaline magmas at mid to lower crustal levels: experimental and petrologic constraints. Periodico di Mineralogia 76(2-3):309325. doi: $10.2451 / 2007 \mathrm{pm} 0030$

Ulmer P, Luth RW (1991) The graphite-COH fluid equilibrium in $\mathrm{P}$, $\mathrm{T}$, fO2 space: an experimental determination to $30 \mathrm{kbar}$ and 1600 \& \#xB0;C. Contrib Mineral Petrol 106(3):265-272. doi:10.1007/ bf00324556

Ulmer P, Kaegi R, Muentener O (2014) Fractional and equilibrium crystallization of primary, hydrous arc magmas at lower crustal conditions. An experimental study at $1.0 \mathrm{GPa}$. J Petrol submitted

Vigneresse JL, Barbey P, Cuney M (1996) Rheological transitions during partial melting and crystallization with application to felsic magma segregation and transfer. J Petrol 37(6):15791600. doi:10.1093/petrology/37.6.1579

Villiger S, Ulmer P, Müntener O, Thompson AB (2004) The liquid line of descent of anhydrous, mantle-derived, tholeiitic liquids by fractional and equilibrium crystallization - an experimental study at $1.0 \mathrm{GPa}$. J Petrol 45(12):2369-2388. doi:10.1093/ petrology/egh042

Villiger S, Ulmer P, Müntener O (2007) Equilibrium and fractional crystallization experiments at $07 \mathrm{GPa}$; the effect of pressure on phase relations and liquid compositions of tholeiitic magmas. J Petrol 48(1):159-184. doi:10.1093/petrology/eg1058

Wager L, Deer W (1939) The petrology of the Skaergaard intrusion, Kangerlassuaq. East Greenland. Medd Groenl 105(4):1-352

Wall VJ, Clemens JD, Clarke DB (1987) Models for granitoid evolution and source compositions. J Geol 95(6):731-749

Whitaker ML, Nekvasil H, Lindsley DH, McCurry M (2008) Can crystallization of olivine tholeiite give rise to potassic rhyolites? an experimental investigation. Bull Volc 70(3):417-434. doi:10. 1007/s00445-007-0146-1

Williams H, Turner FJ, Gilbert CM (1955) Petrography: an introduction to the study of rocks in thin section. W. H. Freeman and Company, San Francisco 